\title{
Age as a risk factor in vasculitis
}

\author{
Andrea D. Gloor ${ }^{1} \cdot$ Gerald J. Berry $^{2}$ · Jorg J. Goronzy ${ }^{1,3} \cdot$ Cornelia M. Weyand ${ }^{1,3}$
}

Received: 13 November 2021 / Accepted: 12 January 2022 / Published online: 9 February 2022

(c) The Author(s) 2022

\begin{abstract}
Two vasculitides, giant cell arteritis (GCA) and Takayasu arteritis (TAK), are recognized as autoimmune and autoinflammatory diseases that manifest exclusively within the aorta and its large branches. In both entities, the age of the affected host is a critical risk factor. TAK manifests during the 2nd-4th decade of life, occurring while the immune system is at its height of performance. GCA is a disease of older individuals, with infrequent cases during the 6th decade and peak incidence during the 8th decade of life. In both vasculitides, macrophages and $T$ cells infiltrate into the adventitia and media of affected vessels, induce granulomatous inflammation, cause vessel wall destruction, and reprogram vascular cells to drive adventitial and neointimal expansion. In GCA, abnormal immunity originates in an aged immune system and evolves within the aged vascular microenvironment. One hallmark of the aging immune system is the preferential loss of $\mathrm{CD} 8^{+} \mathrm{T}$ cell function. Accordingly, in GCA but not in TAK, $\mathrm{CD} 8^{+}$effector $\mathrm{T}$ cells play a negligible role and anti-inflammatory $\mathrm{CD} 8^{+} \mathrm{T}$ regulatory cells are selectively impaired. Here, we review current evidence of how the process of immunosenescence impacts the risk for GCA and how fundamental differences in the age of the immune system translate into differences in the granulomatous immunopathology of TAK versus GCA.
\end{abstract}

Keywords Giant cell arteritis $\cdot$ Takayasu arteritis $\cdot$ Immunosenescence $\cdot$ mTOR $\cdot$ CD ${ }^{+}$Treg cells $\cdot$ NOTCH . Inflammaging

\section{Introduction}

The healthy immune system has multiple mechanisms in place to protect the heart and the large blood vessels from inappropriate inflammation, a mechanism often called immune privilege. Accordingly, autoimmune disease of the myocardium, the aorta, and the large elastic arteries is rare [1, 2]. Insufficiently controlled vascular inflammation is now recognized as a major disease component of atherosclerotic disease. Treatment trials have demonstrated that inflammatory cytokine IL-1 blockade is sufficient to protect at-risk patients

This article is a contribution to the special issue on: Inflammation in vascular diseases - Guest Editors: Mariana Kaplan \& Peter Grayson

Cornelia M. Weyand

cweyand@stanford.edu; weyand.cornelia@mayo.edu

1 Department of Medicine, Stanford University School of Medicine, Stanford, CA, USA

2 Department of Pathology, Stanford University School of Medicine, Stanford, CA, USA

3 Mayo Clinic Alix School of Medicine, College of Medicine and Science, Rochester, MN, USA from recurrent cardiovascular events [3] and the anti-inflammatory medication colchicine has been shown to be vasoprotective [4]. Also, recent evidence that clonal hematopoiesis is a strong risk factor for atherosclerotic disease emphasizes the pathogenic connection between malfunction of myeloid immune cells and inflammation in the atherosclerotic plaque [5-7]. Among inflammatory diseases affecting the aorta and its major branches, atherosclerotic disease is frequent while autoimmune vasculitides are rare. The risk for both disease categories is strictly age-dependent. Atherosclerotic disease and giant cell arteritis (GCA) occur in older individuals, whereas Takayasu arteritis (TAK) is a disease that affects primarily young individuals. Age is such an important risk factor that it has been integrated as a classification criterion for both GCA and TAK. The age range for TAK has been set as below 40 years of age; some patients may have onset of symptoms in their early forties. GCA is diagnosed exclusively in over 50 -year-old individuals $[8,9]$. How young age predisposes to TAK and old age influences susceptibility to GCA or atherosclerosis are not well understood.

Age as a disease risk factor is increasingly recognized as the older adult population expands, and age-related morbidities create an increasing burden of disease. The 
recent COVID-19 pandemic has exemplified host age as a major determinant of disease outcome [10, 11]. In 2019, the average life expectancy of a 60 -year-old American was 83.1 years, meaning that nearly one-third of life is lived beyond age 60 [12]. While it is still unclear whether organ systems age in tandem, it is undebatable that aging of the immune system is intimately linked to aging-related morbidities, including the exponentially higher risk of older individuals to develop cardiovascular disease, cancer, and neurodegenerative disease and to succumb to infections $[10,13]$. With increasing age, tissues undergo structural and functional alterations, and the innate and adaptive immune system deteriorates by immunosenescence [10, 14]. In addition to weakened immune defenses against infections and decreased response to vaccinations, the aging immune system tends to become more inflammatory and more autoreactive. The chronic low-grade inflammation associated with immune cell age is now recognized as "inflammaging." The term captures the co-occurrence of aging with the increased propensity of inflammatory immune responses. In turn, inflammaging alters tissue structures and metabolic and immune functions [14-16]. Together, they increase the threat of a broad spectrum of diseases and organ failure [10, 17]. It is now understood that the immune aging process begins in the 3rd decade of life and accelerates after the age of 50 years [18-20]. As a rule, the adaptive immune system is immature during early life, matures during the 1st and $2 \mathrm{nd}$ decade of life, and remains highly functional over the next three decades. Innate immune responses, mediated by the myeloid cells of the hematopoietic system, are well balanced during early and middle life but become unopposed in older individuals, rendering the host susceptible to uncontrolled tissue inflammation.

Here, we will review the advances in understanding the aging of the human immune system, how immunosenescence can cause immunopathology with an emphasis on age-related restructuring of the immune system in GCA and TAK.

\section{Aging of the immune system}

The immune system protects the integrity of the host by recognizing and destroying infectious, neoplastic, and other injurious agents. Humans possess two major tightly interlinked immune subsystems, the innate and the adaptive systems. The innate system is responsible for swift immunity by utilizing inherited receptor structures and is subject to high cellular turnover. Most innate immune cells live only hours to weeks requiring constant replenishment. Any aging-related changes in hematopoiesis will affect the production and functionality of myeloid cells and impact innate immunity. The adaptive immune system consists of clonally distributed $\mathrm{T}$ cells and $\mathrm{B}$ cells equipped with highprecision antigen receptors. $\mathrm{T}$ and $\mathrm{B}$ cells undergo sophisticated selection processes to minimize autoantigen recognition by their somatically acquired receptors. The need for innate and adaptive immune cells to provide lifelong protection against neoplasms and infections while providing lasting support for tissue repair and regeneration places these constituent inflammatory cells under enormous demand and proliferative pressures. T cells and B cells are the carriers of lasting immune memory, linking their long-term survival to the immunocompetence of the host. Immune cells are highly mobile and need to adapt to varying tissue environments, adding to cellular stress and attrition.

Both the innate and adaptive immune systems change profoundly with progressive age due in part to the everchanging landscape of exposures and the changing dynamics in immune cell generation and replenishment [19]. The immune systems of a 25-year-old patient with TAK and a 75-year-old patient with GCA are fundamentally different, yet both produce autoimmune tissue inflammation with granulomatous infiltrates. Both diseases are treated with immunosuppressive medications that reshape the immune system and challenge the patient's ability to generate protective immune responses [21].

\section{Dendritic cells and macrophages}

Most dendritic cells (DC) and macrophages $(\mathrm{M} \phi)$ are myeloid cells that support immunity through a broad range of functional capabilities. Due to high-density HLA molecules on their cell surface and a specialized three-dimensional structure, DC are believed to be uniquely equipped to prime naïve $\mathrm{T}$ cells and provide the link between innate and adaptive immunity. M $\phi$ present antigens to T cells, mostly memory $\mathrm{T}$ cells but also participate in phagocytosis, efferocytosis, tissue cleanup, and secretion of cytokines, chemokines, enzymes, and metabolites. DC and $\mathrm{M} \phi$ change phenotypically and functionally with age $[22,23]$. In some studies, senescent DC release lower amounts of cytokines (type I interferons (IFNs) and tumor necrosis factor alpha (TNF $\alpha$ ). In other studies, old DC like most myeloid cells that are replenished from old stem cells, acquire a more pro-inflammatory phenotype with high baseline cytokine production even in the absence of TLR triggering. Senescent DC are compromised in recruiting and priming naïve $\mathrm{T}$ cells, but remain competent in supporting pro-inflammatory $\mathrm{T}$ cells, specifically cytokine-dependent effector $\mathrm{T}$ cells [24]. DC are protectors of immune tolerance, and DC aging jeopardizes this function. Immature DCs continually sense self-antigens and contribute to self-tolerance by promoting Treg cell differentiation, whereas senescent DCs lose parts of their tolerogenicity and become immune-stimulating DCs [25]. 
The ability of somatic cells to enter the cell cycle and duplicate is limited. Replication-associated accumulation of damaged DNA, eroded telomeres, and aged mitochondria all result in cell death, or alternatively, cell cycle arrest and senescence [26, 27]. Data collected over the last decade have shown that senescent cells are far from non-functional but instead adapt and acquire new capabilities. Senescenceassociated secretory phenotype (SASP) is characterized by the release of a variety of growth factors, cytokines, and pro-inflammatory mediators $[28,29]$. In humans, $M \phi$ are end-differentiated myeloid cells and do not truly fulfill the criteria of senescence, e.g., entry into an irreversible cell cycle arrest. But, like other cell types, they adapt to a secretory program with age [13]. Accordingly, aged $\mathrm{M} \phi$ are reported to respond to TLR stimulation with the secretion of high amounts of pro-inflammatory cytokines (TNF $\alpha$, IL-6, and IL-1ß), generation of reactive oxygen species (ROS), and activation of the inflammasome [23]. In addition, data are emerging that the expression of co-stimulatory and coinhibitory molecules on $\mathrm{M} \phi$ is altered and tends to become dysregulated with age $[30,31]$. The term "macrophaging" reflects the concept of $\mathrm{M} \phi$ as a key driver for the subtle, chronic, subclinical inflammatory state of older individuals [15, 32], although the data is conflicting. Some studies of $\mathrm{M} \phi$ from aged rodents have produced opposite results, with decreased production of pro-inflammatory cytokines and ROS following stimulation with LPS and IFN $\gamma$ [33-35]. Some investigators have considered a potential role of chronic receptor stimulation resulting in $\mathrm{M} \phi$ aging. This could be particularly relevant for damage-associated molecular patterns (DAMPs), endogenous nuclear, or cytosolic proteins released by damaged or dying cells. DAMPs are sensed by $\mathrm{M} \phi$, providing important information about the tissue microenvironment, and trigger a shift to a pro-inflammatory response designed to initiate tissue repair. As the host ages, exposure to infectious pathogens accumulates, forcing the hematopoietic system to keep up with the production of myeloid cells. Chronic exposure to DAMPs with aging could reprogram $M \phi$, deviating them to become harmful instead of beneficial [36]. Exposure of hematopoietic cells to a variety of inflammatory and metabolic conditions triggers a program of trained immunity $[37,38]$. Training, acquired in the bone marrow environment, enables $\mathrm{M} \phi$ to retain longterm imprinting of microbial encounters. Epigenetic profiles, transcription factors, and micro-RNA networks have all been implicated in this process of reeducation of $\mathrm{M} \phi$ [39].

A dominant mechanism through which aging can reshape innate immunity is clonal hematopoiesis [40]. Somatic mutations that accumulate with progressive age may provide a fitness advantage for some cells, e.g., mutated hematopoietic stem cells producing offspring with the competitive advantage will give rise to clonal populations, also known as clonal hematopoiesis of indeterminate potential (CHIP).
Stem cell mutations ultimately lead to mutated immune effector cells, mostly monocytes and granulocytes. Studies have shown that CHIP is associated with an increased risk of atherosclerotic cardiovascular disease [41]. An excellent example of how aging-associated mutations in hematopoietic progenitor cells can lead to uncontrolled tissue inflammation is VEXAS syndrome. Somatic mutation in the UBA1 gene of hematopoietic progenitor cells causes a chronic, progressive autoinflammatory disease in older men with dermatologic, vascular, and hematologic manifestations [42, 43]. To date, there is no evidence of a parallel disorder involving clonal granulocyte and monocyte populations which are relevant in the age group susceptible to GCA.

\section{T cells and B cells}

Immune memory, including recalling previous encounters to pathogens and vaccines, can last a lifetime. Essentially, all autoimmune diseases depend on the induction of $\mathrm{T}$ cell and B cell memory, which creates a particular therapeutic hurdle, i.e., the need to eliminate immune memory before true remission can be reached. The reliance of autoimmunity on $\mathrm{T}$ and $\mathrm{B}$ cells identifies the immune aging process as a critical component of disease risk. As a rule, $B$ cells require help from $\mathrm{T}$ cells to develop into antibody-producing effector cells, rendering them highly susceptible to aging-imposed deficiencies in the T cell compartment. B cells undergo agerelated changes in subset distribution and function. Older individuals expand a highly differentiated pro-inflammatory $B$ cell phenotype with reduced ability to mount efficient antibody responses [16]. Mechanisms of immunosenescence are much better understood for $\mathrm{T}$ cells.

The adult human body possesses about $4 \times 10^{11} \mathrm{~T}$ cells [43]. The immune system has mechanisms to maintain $\mathrm{T}$ cell numbers, with the exception of the last decade of life, when circulating $\mathrm{T}$ cell numbers decline noticeably and very old individuals develop frank lymphopenia. Based on studies in peripheral blood, the $\mathrm{T}$ cell receptor repertoire in healthy humans contains $10^{7}$ to $10^{8}$ different clonotypes, with clear age-imposed compression of diversity [44, 45]. In patients with rheumatoid arthritis (RA), the TCR repertoire is tenfold smaller, supporting the concept that RA is associated with premature immune aging [46].

To achieve preservation of the $\mathrm{T}$ cell pool and to secure protective immune memory, the host must balance $\mathrm{T}$ cell loss and regeneration. Given the constant demand for $\mathrm{T}$ cells to fight infections and malignant cells, aging imposes a lymphoreplete condition. Humans deal with this problem by producing new T cells in the thymus during the first and second decade of life and then switch to $\mathrm{T}$ cell replenishment by the homeostatic proliferation of circulating post-thymic $\mathrm{T}$ cells $[47,48]$. By the third decade of life, the involuted thymus contributes only a minor proportion of the $\mathrm{T}$ cells produced 
daily. Instead, T cell loss imposes proliferative pressure on available T cells. Human T cells express telomerase and can, to some extent, repair telomeres; however, as somatic cells, T cells can only undergo a limited number of divisions [49]. This is the major hurdle for $\mathrm{T}$ cell replenishment in older adults. In contrast, mice replenish their $\mathrm{T}$ cell compartment exclusively by thymic output [50], sharply limiting their use in studies of immune aging.

$\mathrm{T}$ cells are among the body's longest-lived cells and can survive from childhood to advanced age. Nucleotide sequencing studies in identical twins have identified shared $\mathrm{T}$ cell clonotypes that persist for $>50$ years and represent the progeny of $\mathrm{T}$ cells generated during fetal development [51]. While some long-lived T cells may actually persist as quiescent cells, many will be constantly regenerated by proliferation from the original clone. The coordinated action of homeostatic T cell proliferation and lifelong antigenic challenge leads to skewing of the $\mathrm{T}$ cell repertoire toward differentiated effector and memory $\mathrm{T}$ cells, considered a hallmark of immune aging [20,22]. Some viral pathogens, specifically members of the Herpesviridae family, cause chronic infection and co-exist with the host. Accordingly, cytomegalovirus (CMV), Epstein-Barr virus (EBV), and varicella-zoster virus (VZV) are likely modulators of the adaptive immune system in the aging adult [52, 53].

Continuous proliferative pressure and persistent antigenic stimulation will eventually shrink the naïve $\mathrm{T}$ cell pool and increase the number of end-differentiated $\mathrm{CD} 4^{+}$and $\mathrm{CD} 8^{+}$ cells, so-called TEMRA cells, considered late-stage memory $\mathrm{T}$ cells $[20,54]$. Another outcome of immune stress is $\mathrm{T}$ cell senescence or exhaustion, major determinants in the reduced capacity to eliminate cancer cells in older individuals [55-57]. Accumulation of end-differentiated $\mathrm{CD} 4^{+} \mathrm{T}$ cells is a hallmark of the immune system in patients with atherosclerotic disease, where these "old" $\mathrm{T}$ cells function as tissue-residing IFN-gamma producers [58-60] and mediate cytotoxicity against endothelial cells [61].

The propensity of the aged immune system to tolerate inflammatory activity may reflect the diminished function of regulatory $\mathrm{T}$ (Treg) cells. Tregs function as critical regulators of tolerance and autoimmunity by controlling the intensity and duration of innate and adaptive immune responses. Like all $\mathrm{T}$ cells, Tregs are subject to the aging process and their repertoire and function decline with progressive age [62]. Although the percentages and absolute numbers of $\mathrm{CD}^{+}{ }^{+}$and $\mathrm{CD} 8^{+}$Treg cells are higher in older individuals, inducible $\mathrm{CD}^{+}{ }^{+}$and $\mathrm{CD}^{+}$Tregs are reduced, and their functional activity is impaired [62]. Aged $\mathrm{CD}^{+}$Tregs are less capable of controlling syngeneic $\mathrm{CD} 4^{+} \mathrm{T}$ cells but still suppress allogeneic $\mathrm{CD} 4^{+} \mathrm{T}$ cells. Thus, senescent $\mathrm{CD} 4^{+}$Tregs may fail to protect against autoimmunity [63]. Evidence has emerged that the less studied $\mathrm{CD} 8^{+}$Tregs hold an important position in protecting the host from autoimmunity [64]. Like
$\mathrm{CD}^{+}{ }^{+}$Treg cells, aged $\mathrm{CD} 8^{+}$Tregs show a reduced ability to suppress proliferation and cytokine production of $\mathrm{CD}^{+}$ effector T cells. A population of exosome-producing CD8 ${ }^{+}$ Treg cells appears particularly susceptible to aging-induced loss-of-function [65]. These cells derive from naïve $\mathrm{CD} 8^{+}$ $\mathrm{T}$ cells, and of all $\mathrm{T}$ cell populations, naïve $\mathrm{CD} 8^{+} \mathrm{T}$ cells are the most susceptible to the aging process [66].

The last decade has produced major advances in identifying mechanisms of lymphocyte differentiation into memory $\mathrm{T}$ and $\mathrm{B}$ cells and clarified where and how memory cells persist [67]. Tissue-resident memory T cells ( $\mathrm{Trm})$ survive and act locally in barrier tissues and respond promptly to antigen reexposure, e.g., reinfection. They depend on specialized tissue niches to support their fitness, function, and plasticity. How tissue aging impacts Trm is not well understood, but emerging data support a role for tissue-deposited memory $\mathrm{T}$ cells in inducing immunopathology in autoimmune inflammation [68]. Figure 1 highlights the major shifts in the cellular composition of the immune system over a lifetime and summarizes current knowledge about pathways that are relevant in immune aging.

\section{Age-related changes in blood vessels}

The vascular system is a life-sustaining organ composed of networks of arteries, arterioles, and capillaries transporting blood containing oxygen, micro- and macronutrients, metabolic end-products, and immune and progenitor cells [69]. The vascular inner intimal layer directly interfaces with a wide range of external and internal stimuli. In addition, medium and large arteries have a constituent vascular support system, the vasa vasorum. Localized within the adventitia, vasa vasora provide access for oxygen and nutrients to the vessel wall layers and act as the interface between the target tissue and the infiltrating immune cells in large-vessel vasculitis [70]. Vascular disease is the leading cause of aging-associated morbidity and mortality in the USA. By far, the most frequent disease process manifesting in aging blood vessels is atherosclerosis, but little is known about the precise steps of vascular failure induced by progressive age [71, 72]. Aging entails various detrimental effects on extracellular and cellular components in vascular tissues. Much emphasis has been put on the potential injurious impact of reactive oxygen species, but therapeutic attempts to ameliorate cardiovascular disease with antioxidant therapies have proven largely unsuccessful [73]. With age, the disturbed balance between the production and neutralization of ROS leads to oxidative damage to DNA and cellular structures and changes in intracellular signaling [74]. Advanced glycation end-products (AGE), which are markedly increased with age, are formed by a nonenzymatic reaction of proteins, 


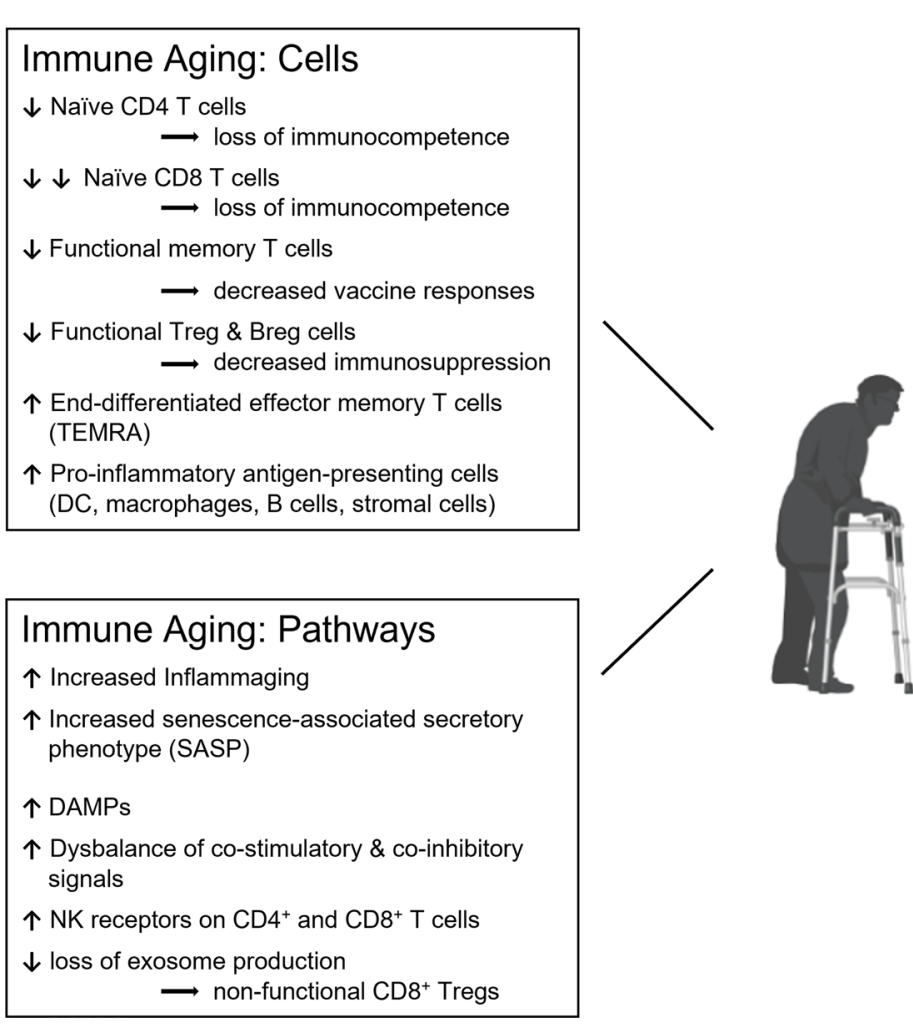

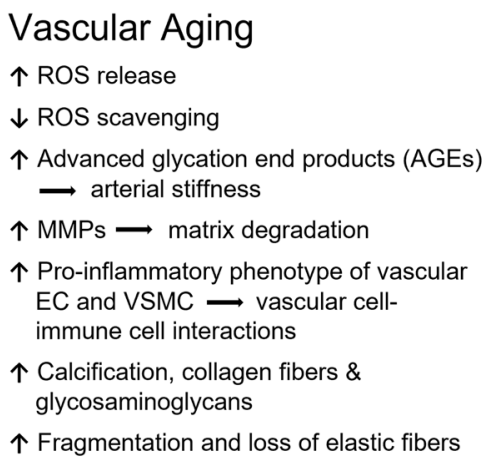

Senescence-associated epigenetic and microbial changes

$\uparrow$ Microbial load of the host

$\downarrow \uparrow$ DNA methylation

$\uparrow \downarrow$ Histone expression \& modification

$\uparrow$ Variation in miRNA profiles

$\uparrow$ Gut microbiome dysbiosis

$\uparrow$ Microbial metabolites
Fig. 1 The interface of aging and vascular inflammation. The cellular and molecular pathophysiology of organismal aging is becoming increasingly understood, and it is now recognized that the aging process is a major disease risk factor. Most aging-associated morbidities are closely connected to the failure of the immune system, including the host's inability to fight infections and cancers and to repair and

lipids, or nucleic acids with sugar molecules. AGEs can produce arterial stiffness and vessel wall damage by inducing crosslinking of extracellular matrix proteins, oxidation of low-density lipoprotein (LDL), and promoting inflammatory pathways in endothelial cells (EC) [75]. Arterial wall remodeling associated with aging also involves matrix metalloproteinases (MMPs), which degrade the extracellular matrix (ECM) and activate pro-inflammatory molecules such as monocyte chemoattractant protein-1 (MCP-1) and transforming growth factor-beta 1 (TGF$\beta 1)[76,77]$. Senescent EC and vascular smooth muscle cells (VSMC) adopt a pro-inflammatory phenotype and show altered interaction with immune cells (e.g., enhanced chemotaxis and expression of adhesion molecules such as VCAM1 and ICAM1) [78]. Other structural changes including fragmentation and loss of elastic fibers, mural calcification, increase of collagen fibers and accumulations of glycosaminoglycans in the medial layer, and expansion of smooth muscle cells and extracellular matrix in the intimal layer produce vascular thickening, diminished compliance, and stiffening (Figs. 1 and 2) [79]. How these structural changes participate in the molecular processes maintain intact tissues. The aging immune system loses competence and shifts toward unopposed inflammatory activity, a process called "inflammaging." The risk of older adults to develop autoimmune vasculitis relates to progressive immune aging, structural changes in the tissue environment of the vessel wall, alterations in genetic and epigenetic stability, and aging-induced adaptations of the host microbiome

that disrupt the immune privilege inherent to the walls of the large elastic arteries is currently unknown.

\section{Age-dependent immunopathology in GCA and TAK}

GCA is a granulomatous arteritis affecting the 2 nd -5 th branches of the aorta. Inflammatory lesions are centered on the aortic and arterial wall and are composed primarily of highly activated macrophages and $\mathrm{T}$ cells eliciting a maladaptive response-to-injury mechanism. The disease is exclusively diagnosed in individuals over 50 years of age. The average age in cohorts of GCA patients lies in the middle of the 8th decade of life, with a remaining life expectancy of less than 10 years. The disease has an extravascular component, presenting with an intense acute phase response, highly elevated hepatic acute phase proteins, myalgias, and constitutional symptoms such as painful stiffness of select muscular territories, described as polymyalgia rheumatica (PMR), fever, weight loss, and failure-to-thrive [80, 81].

While the vascular territory and the clinical manifestations are largely overlapping, GCA and TAK affect two non-overlapping patient populations. Like GCA, TAK is a 


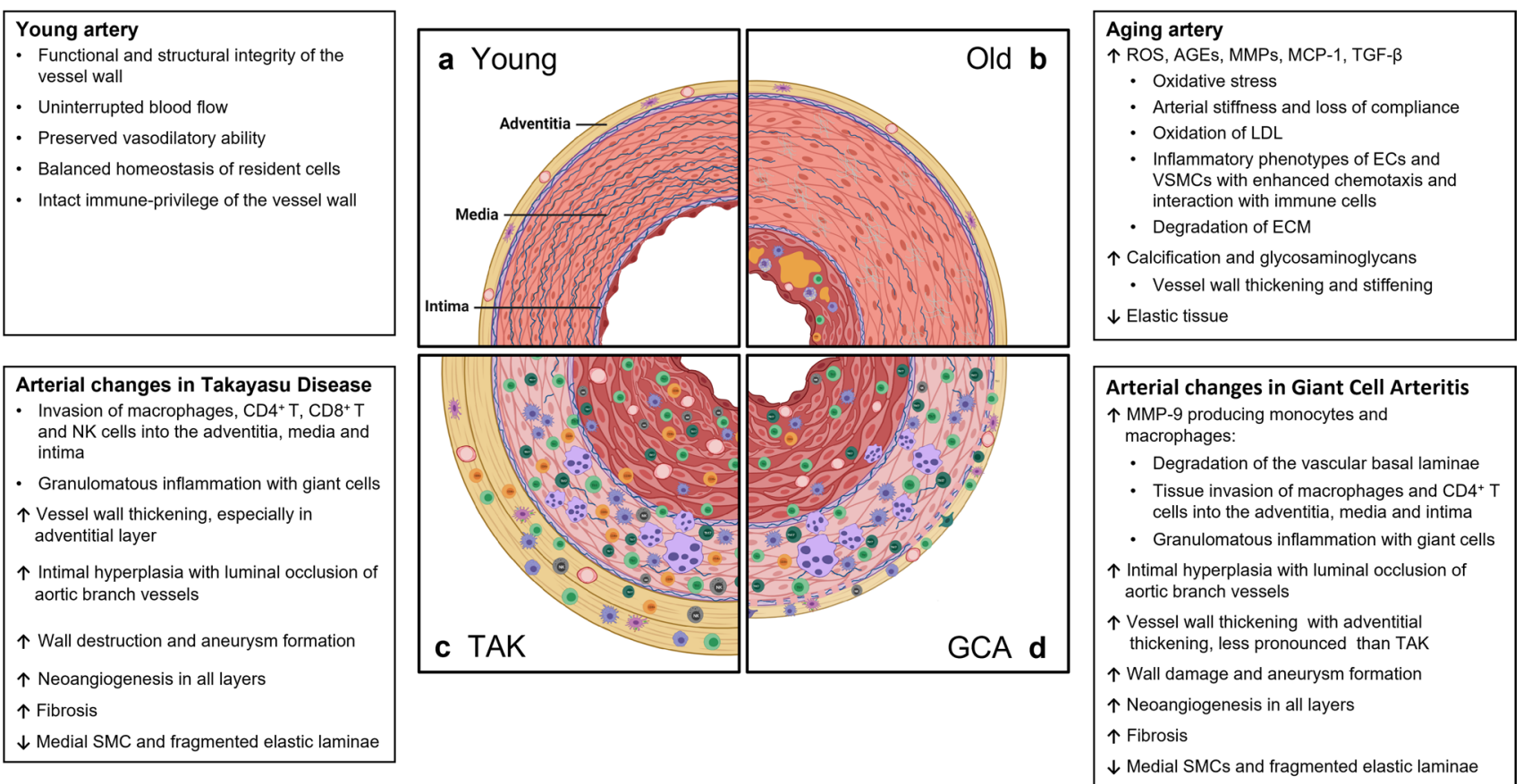

Fig. 2 Vascular microenvironments in young, old, and inflamed arteries. Medium and large arteries must withstand lifelong mechanical stress, requiring maintenance of vasoconstrictor/vasodilator capacity and preservation of anticoagulant and anti-inflammatory surfaces. The vessel wall is an immunoprivileged tissue niche protected from the invasion of inflammatory cells. In the medium/largevessel vasculitides, Takayasu arteritis and Giant cell arteritis, the immune privilege of the vessel wall is broken, and macrophages and $\mathrm{T}$ cells invade into the adventitia and media to form granulomatous

granulomatous arteritis of the aorta and its primary branches $[80,82]$. However, there are key differences in the composition of the inflammatory infiltrates as well as in the histological appearance of the inflamed vessel wall [21], suggesting similarities and differences in the pathomechanisms underlying both diseases. In the active phase, TAK is characterized by granulomatous aortitis with distinctive thickening of the medial and adventitial layers compared to GCA, resulting in the imaging changes in the ascending aorta (Figs. 2 and 3). Typically, the granulomatous infiltrates of TAK contain increased proportions of $\mathrm{CD}^{+} \mathrm{T}$ cells and natural killer cells, suggesting a role for cell-mediated toxicity (Figs. 3 and 4) [21]. This is not unexpected, given that the granulomatous lesions of TAK are formed by a younger immune system, as opposed to the granulomatous infiltrates of GCAaffected arteries where $\mathrm{CD} 8^{+} \mathrm{T}$ cells are at low abundance due to aging-imposed restructuring of the immune system (Fig. 5) [83]. TAK can affect teenagers with a peak incidence in the third decade, a period wherein the immune system is still supplied by high thymic output. A diagnosis of TAK in individuals older than 40 years should only be considered if there is evidence for disease onset prior to 40 years of age. Currently, there are no data indicating prematurity of the infiltrates. The vessel wall responds with a maladaptive response-toinjury, resulting in thickening of the adventitia, intramural neoangiogenesis, and intimal hyperplasia. Clinically relevant outcomes are arterial stiffening, aortic aneurysm formation, and ischemia-inducing luminal stenosis of aortic branch vessels. Cellular infiltrates are shaped by the host immune system, containing $\mathrm{CD} 4^{+}$and $\mathrm{CD} 8^{+} \mathrm{T}$ cells in the young TAK patients and predominantly $\mathrm{CD} 4^{+}$effector $\mathrm{T}$ cells in the old GCA patient

immune senescence process in either TAK or GCA patients, in contrast to rheumatoid arthritis [84]. Age is also a recognized risk factor in Kawasaki's disease (KD), a febrile illness that primarily affects children younger than 5 years of age and can lead to vasculitic destruction of coronary arteries. Seasonality and community-wide outbreaks in KD have supported the concept that this vasculitis is caused by a maladaptive immune response against an infectious pathogen. Thus, studies in the vasculitides provide an opportunity to examine the impact of chronic inflammatory disease on the immune aging process itself and permit comparisons of pathogenic capabilities of the old versus the young immune system.

\section{Pathogenic dendritic cells and macrophages in large-vessel vasculitis}

Myeloid cells are subject to aging, and comparing myeloid cell populations in GCA and TAK could be informative in identifying specific characteristics of macrophages and dendritic cells in granulomatous inflammation. Dendritic cells that accumulate in the inflamed vascular wall are believed to be of mixed origin, derived partially from the endogenous 
Fig. 3 Histopathology of giant cell aortitis and Takayasu aortitis. A, B. Giant cell aortitis in a 70-year-old woman with an ascending aortic aneurysm is characterized by pan-arterial injury with intimal hyperplasia, inflammation and zones of medial necrosis, and mild fibrous thickening of the adventitial layer (H\&E and trichrome stains). C, D. Takayasu aortitis in a young woman presenting with a murmur and ascending aortic aneurysm. There is conspicuous mural thickening especially of the adventitial layer along with granulomatous inflammation of the medial layer $(\mathrm{H} \& \mathrm{E}$ and trichrome stains)
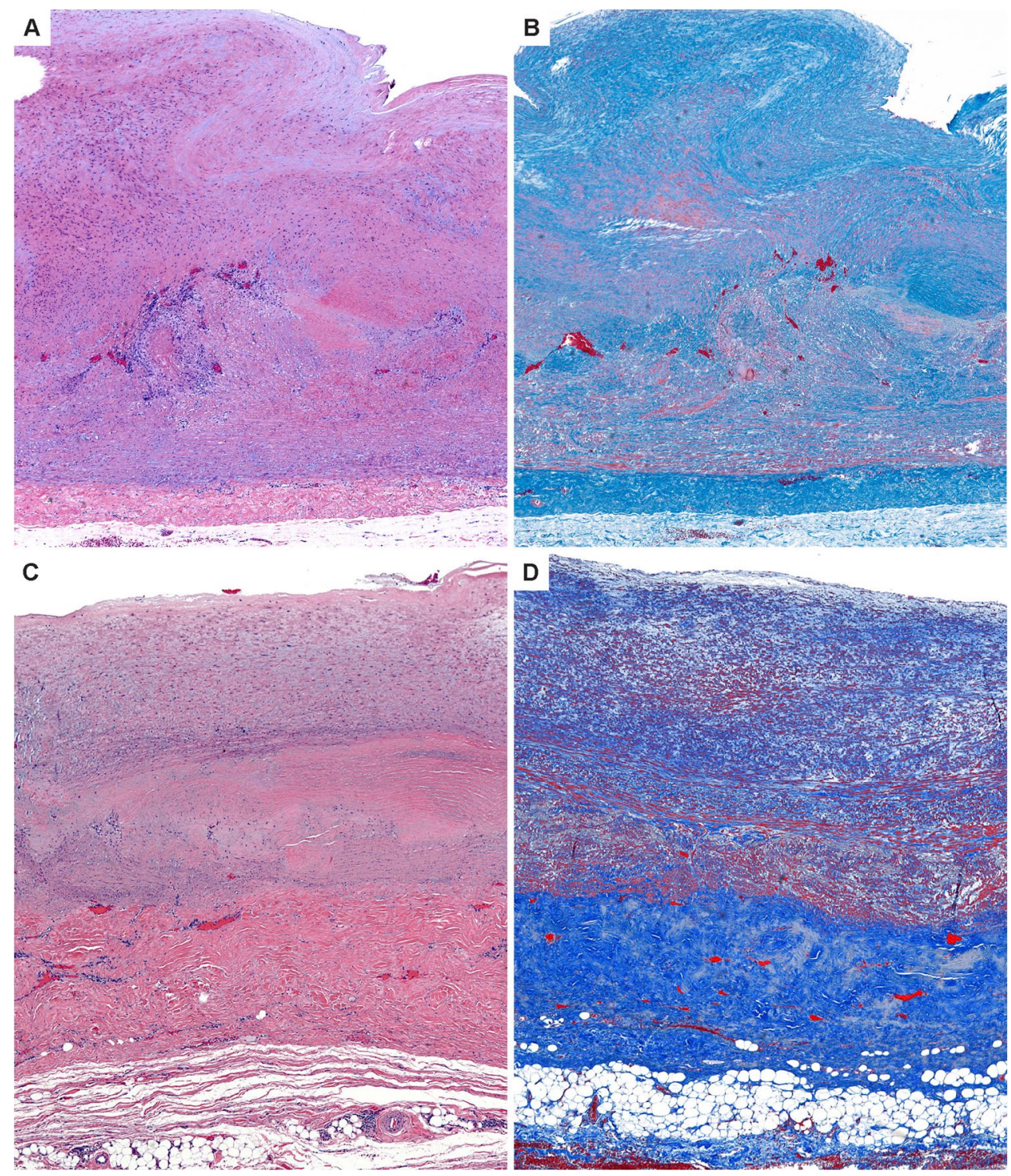

population of vascular DC within tissues and partly from tissue-infiltrating DC originating in the bone marrow [85]. In GCA, they are strategically localized between the adventitia and the media, in close proximity to the vasa vasorum through which infiltrating immune cells reach the target tissue. DC are also part of the cellular infiltrate in atherosclerotic plaque, where they secure in situ recognition of antigens [86]. DC are professional antigen-presenting cells required for the priming of naive $\mathrm{T}$ cells. The activation status, and thus their ability to take up and process antigen, is ultimately determined by the recognition of pathogenderived molecular patterns (PAMP) and danger-associated molecular patterns (DAMP), a process involving Toll-like receptor (TLR) molecules. TLR expression profiles of vascular DC have been obtained for different types of arteries and demonstrate a close correlation between vascular territory and DC function [87]. This territorialism may be critically important in determining the tissue tropism in GCA. Similar studies are currently unavailable in TAK. The best evidence that antigen recognition occurs in the inflamed vessel wall stems from shared $\mathrm{T}$ cell clonotypes in the right and left temporal artery biopsies from GCA patients [86]. Again, information on antigen recognition events in the granulomatous infiltrates of TAK is still needed.

Besides the presentation of HLA-embedded antigenic peptides on their surface, DC guide the antigen-presenting process by providing both positive (co-stimulatory) and negative (co-inhibitory) signals. In GCA, the tissue-resident DC are strongly positive for CD80 and CD86 [88] and the disease process is shaped by CD28-CD80/CD86 interactions [89]. CD28 signaling has been implicated in regulating the metabolic profile of vasculitic $\mathrm{T}$ cells, favoring glycolytic activity but also mitochondrial respiration [89]. Tissueresiding $\mathrm{T}$ cells in GCA are hypermetabolic and depend on 

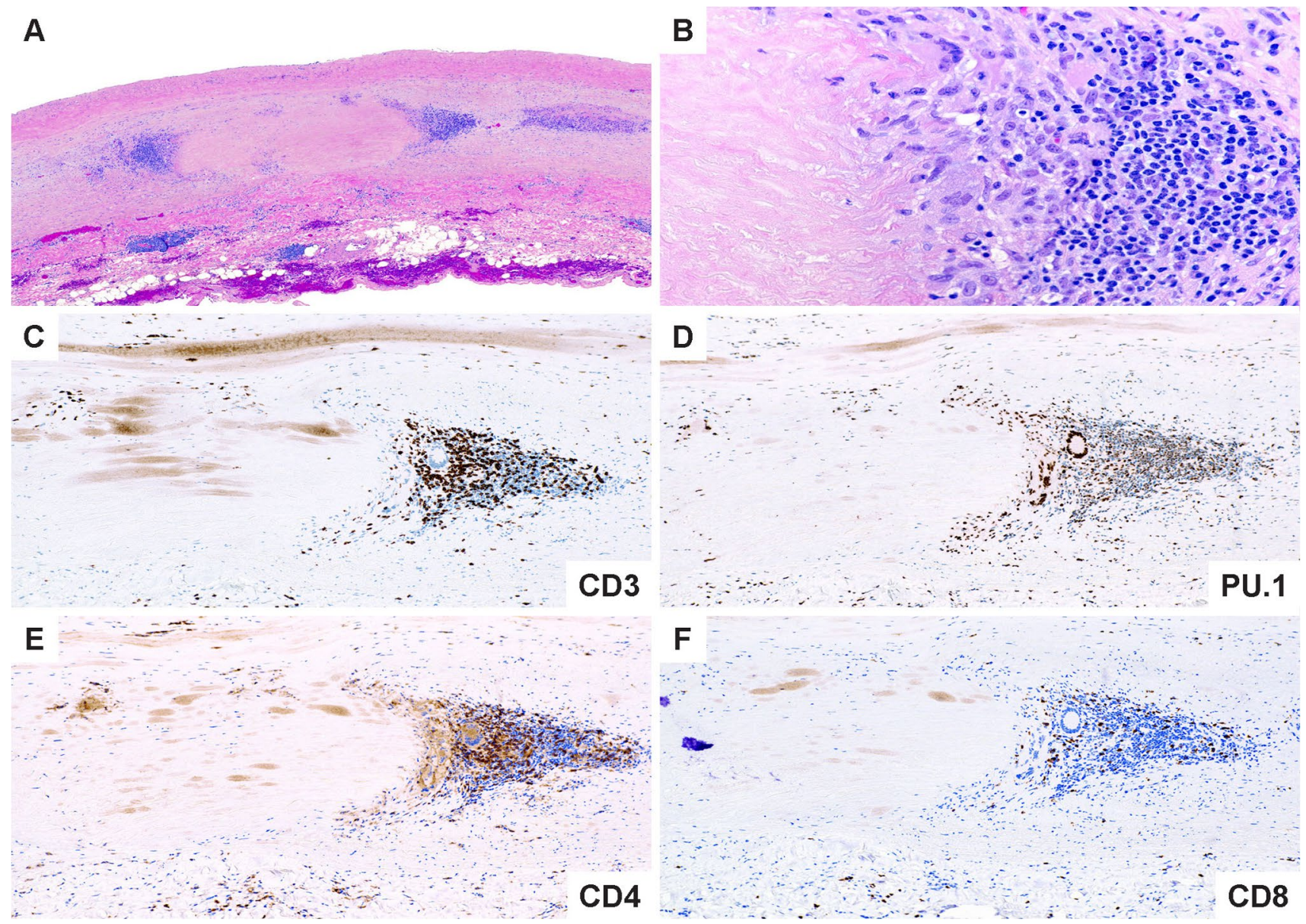

Fig. 4 Immunopathology of giant cell arteritis. A. Low power magnification of GCA characterized by numerous foci of medial inflammation and destruction along with intimal and adventitial inflammation and thickening. B. High power magnification showing an admixture of macrophages including multinucleated cells and lym-

phocytes surrounding the zone of medial necrosis. C. CD ${ }^{+} \mathrm{T}$ cells comprise the majority of cells within the medial layer. D. PU. $1^{+}$macrophages including the multinucleated giant cells. $\mathbf{E}$. The T cell infiltrates are composed primarily of $\mathrm{CD}^{+} \mathrm{T}$ cells. F. Only scattered $\mathrm{CD} 8{ }^{+} \mathrm{T}$ cells are found in the intimal inflammatory focus

an ample supply of glucose and alternative energy carriers [89]. Implicating dendritic cells in setting the threshold for energy consumption of pathogenic $\mathrm{T}$ cells builds an immediate bridge to aging-imposed mechanisms, as the metabolic programming of $\mathrm{T}$ cells is an age-dependent phenomenon [19].

A key functional abnormality of DC in GCA is the low expression of the co-inhibitor molecule PD-L1 [90]. In GCA-positive temporal artery biopsies, vessel wall-residing DC have barely detectable PD-L1. The defect appears to be systemic; DC generated from bone marrow-derived precursors share the PD-L1 low phenotype [90]. PD-L1 on antigen-presenting cells cross-links PD-1 on T cells to transmit a negative signal. PD-1 is critical in shaping an array of $\mathrm{T}$ cell functions, including the induction of $\mathrm{T}$ cell anergy, $\mathrm{T}$ cell exhaustion, $\mathrm{T}$ cell apoptosis, as well as the survival of Treg cells [90, 91]. The importance of the PD-1/PDL-1 signaling pathway in determining the strength and duration of $\mathrm{T}$ cell responses has further elucidated with the therapeutic application of immune checkpoint inhibitors in cancer. Antibodies blocking access to either PD-1 or PD-L1 disrupt excessive signaling in this pathway and unleash $\mathrm{T}$-cell immunity against malignant cells. Notably, cancer patients treated with checkpoint inhibitors can develop a spectrum of autoimmune manifestations, including large-vessel vasculitis $[92,93]$. In GCA, PD-L $1^{\text {low }}$ vascular DC fail to block the differentiation of effector $\mathrm{T}$ cells in the vasculitic lesions, leading to the accumulation of interferon-gamma, IL-17, and IL-21-producing T cells [90]. There is currently no data on the functionality of the PD-1/PD-L1 pathway in TAK. However, the shared deficiency of PD-L1-dependent signaling in cancer and GCA occurs in the setting of advanced age, possibly identifying the failure of this important co-inhibitory pathway as an aging-related pathology.

Macrophages $(\mathrm{M} \phi)$ are a core constituent of the granulomatous lesions in GCA (Fig. 4) and TAK (Fig. 5) and 
Fig. 5 Immunopathology of Takayasu aortitis. A.

Low power magnification of TAK aortitis. The intimal and adventitial layers are expanded by fibroinflammatory tissues. The medial layer shows discrete zones of necrosis surrounded by variable inflammatory collars. B. High power magnification showing a cuff of mononuclear cells including multinucleated giant cells and lymphocytes around the necrotic medial layer. C. Abundant $\mathrm{CD}^{+}{ }^{+} \mathrm{T}$ cells. D. Numerous PU.1 staining macrophages. E. $\mathrm{CD} 4{ }^{+} \mathrm{T}$ cells within the medial inflammatory cluster. F. $\mathrm{CD}^{+} \mathrm{T}$ cells are disproportionately increased compared to GCA

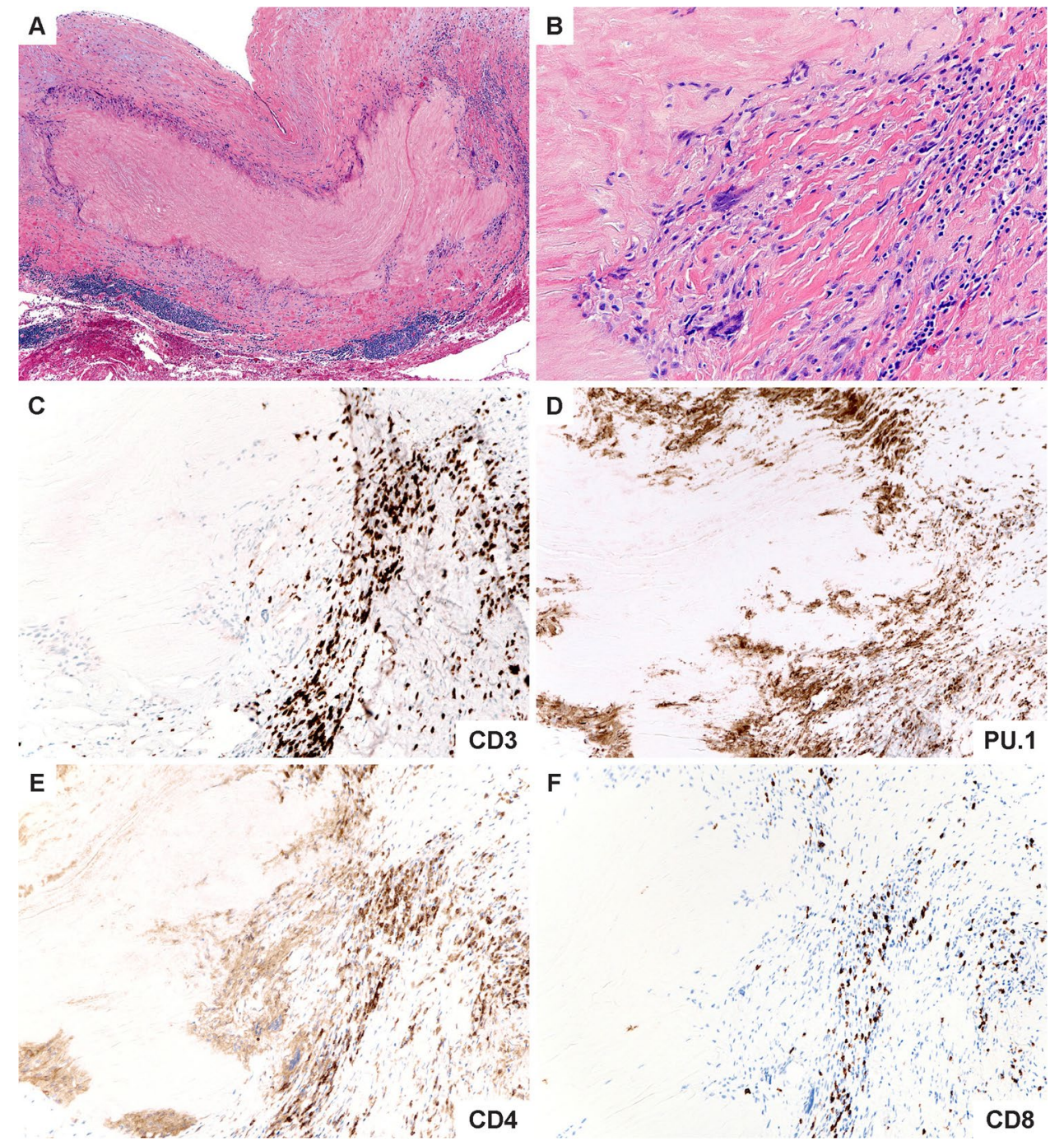

can transition into multinucleated giant cells [80]. As enddifferentiated myeloid cells, $\mathrm{M} \phi$ are highly susceptible to bone marrow aging. $\mathrm{M} \phi$ encountered in inflammatory tissue lesions are heterogeneous, characterized by distinct origins, fate decisions, and differentiation pathways [94, 95]. A comprehensive analysis of the $\mathrm{M} \phi$ heterogeneity in the vasculitic infiltrates is lacking, but currently, the majority are presumed to originate from the bone marrow. Monocytederived $\mathrm{M} \phi$ from GCA patients demonstrate abnormalities in two domains, the production of metalloproteinases, specifically, MMP-2 and MMP-9 and the propensity to produce chemokines $[96,97]$. The ability of GCA M $\phi$ to produce active MMP-9 has been mechanistically linked to tissue invasion in in-vitro and in-vivo studies. Importantly, T cells could not penetrate basal membranes unless supported by MMP- $9^{+}$М $\phi$ [96]. High expression of MMP-9 persists in multinucleated giant cells, suggesting direct involvement in the digestion of vessel wall structures [96]. Antibodies capable of specifically inhibiting the activity of MMP-9 prevented invasion of T cells into the vessel wall, and more importantly, they inhibited the wall remodeling process, including neovascularization and intimal hyperplasia [96]. These data support the concept that MMP production is not simply an epiphenomenon of macrophage activation but is mechanistically linked to the disease process. Whether dysregulation of MMPs also contributes to the pathophysiology of TAK is still controversial. Studies found increased levels of several MMPs (e.g., MMP-2, -3, -9) in the blood of TAK patients; other studies did not support these findings [98]. MMPs have been implicated in the process of vascular aging by directly contributing to wall fibrosis and stiffening [99, 100]. A propensity of GCA and possible TAK monocytes and macrophages to release excessive MMPs may be relevant for the loss of tissue tolerance and, in a feed-forward loop, lead to accelerated aging of the affected vessels.

Despite the hyperactivated state of macrophages participating in the formation of mural granulomatous inflammation, metabolic studies have found that GCA macrophages 
are very similar to age-matched controls [97]. Notably, comparative studies of macrophages in GCA and in coronary artery disease (CAD) have shown striking metabolic differences with high-intensity glycolytic activity and mitochondrial respiration selectively in nonvasculitic CAD patients [97]. While GCA and CAD are diseases of older individuals and dependent on $\mathrm{M} \phi$ for their respective pathophysiology, risk factors and disease mechanisms appear to be disease-specific and not a consequence of immune and vascular aging. The pro-inflammatory state of CAD M $\phi$ has been linked to ROS-induced metabolic reprogramming [101]. Mitochondrial hyperreactivity leads to oxidative modification and dimerization of the glycolytic enzyme PKM2, which then translocates into the nucleus, where it activates STAT3 and promotes IL- $1 \beta$ and IL- 6 production. High production of ROS and mitochondrial stress has also been described for $\mathrm{M} \phi$ that are part of the GCA infiltrates [102]. High mitochondrial ROS release has been considered a hallmark of aging [103]. Applying that paradigm, CAD and GCA M $\phi$ are stressed and aged.

\section{Aberrant mTORC1 signaling in aging and in large-vessel vasculitis}

The mechanistic target of rapamycin (mTOR) is an evolutionarily conserved signaling hub that senses and integrates intracellular energy reserves and growth factor signals to align cell growth, proliferation, and death [104, 105]. The mTOR network measures and responds to the availability of intracellular nutrients and directs autophagy, mitochondrial function, and protein synthesis. mTOR complex 1 (mTORC1) and AMPK are now recognized as the two central metabolic sensors, meeting on the surface of the lysosome to determine cellular longevity and youthfulness versus senescence [106, 107]. Pharmacologic inhibition of mTORC1 is currently being explored as a therapeutic option to extend lifespan [108]. Increased activity of mTORC1 is a distinguishing feature of $\mathrm{CD}^{+}{ }^{+} \mathrm{T}$ cells in both GCA and TAK (Fig. 6) [109], suggesting that these important regulators of granuloma formation have features of senescent $\mathrm{T}$ cells. The regulatory steps determining subcellular distribution and activity of the mTORC1 are complex. A variety of age-related as well as age-independent factors and signaling pathways influence mTORC1 activity [104]. Important mTORC1 regulators are the sirtuins (SIRTs). SIRTs are nicotinamide adenine dinucleotide $\left(\mathrm{NAD}^{+}\right)$-dependent deacetylases that have been implicated in aging and longevity [110]. SIRT1 inhibits mTORC1 by stimulating AMPK via LKB1. Lower $\mathrm{NAD}^{+}$levels cause decreased SIRT1 activity in older individuals. PBMC from GCA patients shows lower SIRT1 activity when compared with age-matched healthy controls, possibly due to increased intracellular ROS levels [111]. Data on SIRT1 in TAK patients are not yet available. The Jagged1-NOTCH1 as well as the CD28-PI3KAKT pathway independently contribute to the regulation of mTORC1 activity, and both were found to be hyperactive in GCA T cells $[89,112,113]$. T cell specification and commitment depend on NOTCH signaling, and in post-thymic T cells, NOTCH signaling transmits a co-stimulatory signal. NOTCH has a role in a variety of other cell types, including macrophages, DCs, ECs, and VSMCs [114, 115]. Besides its essential role in cardiovascular development, the NOTCH signaling pathway has been implicated in multiple agerelated processes and disease states. Notch receptors and ligands are considered to be responsive to inflammatory signaling and act as amplifiers of tissue inflammation by facilitating the crosstalk between immune cells (T cells, M $\phi$ ) and vascular cells (EC, VSMC). Additionally, NOTCH1 appears to have a critical role in aortic aneurysm formation by enhancing $\mathrm{M} \phi$ infiltration into the vascular tissue and increased MMP production [113, 116, 117]. In GCA patients, elevated VEGF levels induce the NOTCH ligand Jagged 1 on microvascular endothelial cells, turning vasa vasora into communication partners for $\mathrm{NOTCH} 1^{+} \mathrm{T}$ cells $[113,118]$. After interacting with Jagged $1^{+} \mathrm{EC}, \mathrm{NOTCH} 1^{+}$ $\mathrm{T}$ cells activate mTORC 1 and turn into cytokine-producing effector cells, making a commitment to the Th1 or the T17 lineage.

Preferential differentiation of $\mathrm{CD} 4^{+} \mathrm{T}$ cells into $\mathrm{Th} 1$ and Th17 effector cells is a consistent feature in TAK patients, where it has been connected to aberrant mTORC1 activity. Hadjadj et al. have reported that the mTOR network is equally activated in EC from TAK patients, an abnormality not seen in GCA [119]. mTORC1 hyperactivity is believed to promote EC expansion, biasing $\mathrm{T}$ cell differentiation toward Th1 and Th17 polarization and impairing Treg cell function in both TAK and GCA. Taken together, mTORC1 hyperactivity is a consistent finding in T cells from TAK and GCA patients, connecting immune dysregulation with a signaling pathway typically seen in senescent cells. While part of this pathology may reflect immune aging in GCA, alternative upstream regulators must be at work in TAK. Anti-endothelial antibodies that are seen in TAK but not in GCA patients may function as EC activators and sustain the aberrant mTOR activation [120].

In GCA CD4 ${ }^{+} \mathrm{T}$ cells, aberrant mTORC 1 activity can also be a consequence of disproportionate co-stimulation through the CD28-PI3K-AKT pathway [90]. While the surface expression of CD28 is similar in GCA and age-matched controls, the sensitivity to an anti-CD28 blocking antibody is much higher in the patients' T cells [90]. CD28-dependent signaling shifted GCA T cells into a hypermetabolic state, enhancing survival, proliferative activity, effector cytokine release, and T-cell-induced macrophage activation [90]. Hyperactivity in the PI3K/AKT pathway has been described in neurodegenerative disorders, such as Alzheimer's and 
a

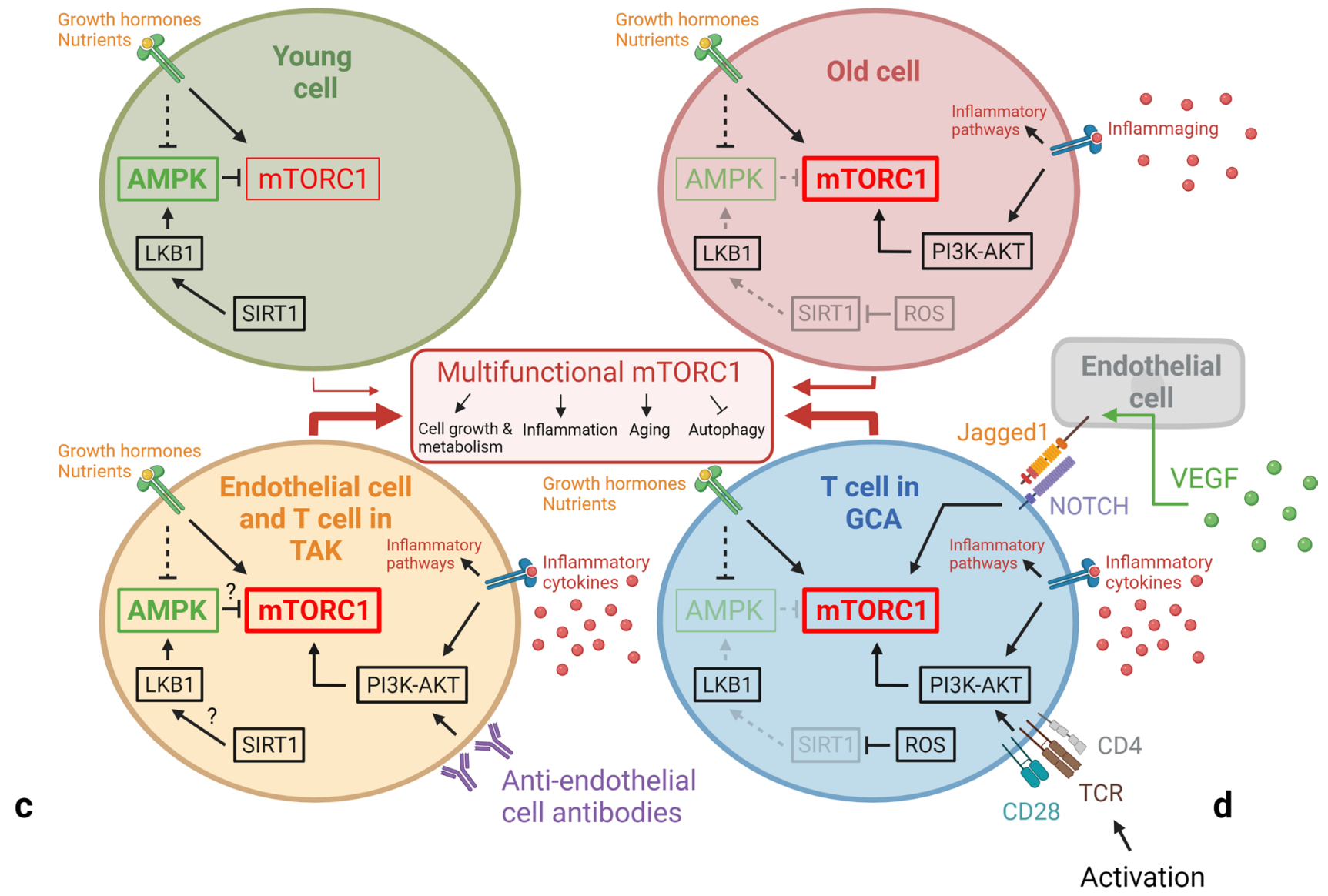

Fig. 6 Aberrant mTORC1 activation on aging and in vasculitis. The mammalian target of rapamycin complex 1 (mTORC1) is the cell's major nutrient/energy/redox sensor and coordinates protein synthesis with the cell's bioenergetics. AMP-activated protein kinase (AMPK) activates catabolic and suppresses anabolic metabolism to secure energy balance. Signaling in the two pathways is closely interconnected and inflammatory effector functions directly dependent on

Parkinson's disease, two conditions strongly associated with aging [121]. Conversely, it could be argued that chronic activation of the NOTCH1 and PI3K/AKT pathway, both targeting mTORC 1 as a downstream target, may simply reflect the chronicity of the disease process, leading to $\mathrm{T}$ cell exhaustion and an aging phenotype.

\section{Shared pathways in vasculitis and immune aging}

Based on chronological age, TAK is a disease of the young and GCA is a disease of the old. In both vasculitides, age outranks other risk factors by far. Nevertheless, no formal analyses have been conducted assessing the phenotypic age of patients affected by TAK or GCA. TAK occurs early in life, making it highly unlikely that immunosenescence has a
mTORC1 and AMPK activation. Increased activity of mTORC1 and diminished activity of AMPK is a hallmark of cellular aging, and the two kinases have become therapeutic targets to extend lifespan. Aberrant mTORC1 activation is now recognized as a typical feature of $\mathrm{T}$ cells in autoimmune vasculitis, where effector differentiation is sustained by signaling of the mTOR network. mTORC1 may also perpetuate the activation status of disease-relevant stromal cell populations

relevant contribution to disease risk. There are no data that could reliably assign TAK as a disease caused by premature aging. Rather, it is likely that the inflammatory process that persists over decades will have negative effects on immune health and impose a state of immune exhaustion. Furthermore, no studies have examined the impact of chronic vascular inflammation on the immunocompetence of TAK patients during old age. Models and concepts of the immunopathology of GCA cannot be separated from senescence-associated abnormalities in the immune system. GCA clearly manifests in individuals with an aging immune system, and aged $\mathrm{M} \phi$ and aged $\mathrm{T}$ cells may excel in forming granulomatous lesions. Here, we will highlight processes that are well established in the field of immunosenescence that might transition individuals from at-risk to vasculitis patients. Table 1a and $1 \mathrm{~b}$ summarize the adaptations in immune cell function in aging and in vasculitis. 


\section{T cell senescence}

Most convincing data derive from the comparative role of $\mathrm{CD}^{+} \mathrm{T}$ cells in GCA and TAK. CD8 ${ }^{+} \mathrm{T}$ cells and natural killer (NK) cells contribute substantially to the aortic wall lesions of TAK, while they are a minor population in the GCA-affected temporal artery and aorta $[122,123]$. A cardinal feature of immune aging is the loss of $\mathrm{CD} 8^{+} \mathrm{T}$ cells. Within the same individual, $\mathrm{CD}^{+} \mathrm{T}$ cells age faster than $\mathrm{CD} 4^{+} \mathrm{T}$ cells and the accumulation of end-differentiated $\mathrm{CD}^{+}{ }^{+} \mathrm{CD} 45 \mathrm{RA}^{+} \mathrm{CCR}^{-}{ }^{-}$effector memory $\mathrm{T}$ cells (TEMRA) is a programmed event during the 2nd half of life [124]. Naïve $\mathrm{CD}^{+} \mathrm{T}$ cells exhibit a much greater decline in absolute and relative cell numbers and a higher expression of senescence markers with aging than $\mathrm{CD}^{+} \mathrm{T}$ cells [125]. Thus, the $\mathrm{CD} 8^{+} \mathrm{T}$ cell pool is much smaller in GCA patients than in TAK patients. Also, with progressive age, the $\mathrm{CD} 4^{+}$ and $\mathrm{CD}^{+} \mathrm{T}$ cell compartments become enriched in $\mathrm{CD} 28$ negative, end-differentiated effector cells, so-called TEMRAs [20]. In parallel, $\mathrm{CD}^{+}$and $\mathrm{CD} 8^{+} \mathrm{T}$ cells evolve to a more NK cell-like phenotype with enhanced expression of NK receptors on their surface and increased cytotoxic capacity [20]. Enrichment of $\mathrm{CD} 4^{+} \mathrm{CD} 28^{-} \mathrm{T}$ cells in the inflamed tissue provided the first clue that patients with rheumatoid arthritis have premature immune aging [126]. $\mathrm{CD} 4{ }^{+} \mathrm{CD} 28^{-} \mathrm{T}$ cells are associated with unstable angina and acute coronary syndrome [59], accumulate within the atherosclerotic plaque [60] and function as cytotoxic $\mathrm{T}$ cells attacking endothelial cells [62, 127], highlighting the importance of TEMRAs in vascular inflammation. Conversely, NK cells lose their cytotoxic capacity while tending to expand with age (especially long-lived NK cells) [20, 128]. As expected, $\mathrm{CD} 4^{+} \mathrm{CD} 28^{-} \mathrm{T}$ cells are increased in the peripheral blood and vascular lesions of GCA patients. These $\mathrm{CD} 4{ }^{+} \mathrm{CD} 28^{-} \mathrm{T}$ cells demonstrate upregulation of the NK receptor NKG2D [129], matching the senescent T cells previously described in rheumatoid arthritis [130] and in ANCA-associated vasculitis [130, 131]. Notably, in lupus, $\mathrm{NKG}_{2} \mathrm{D}^{+} \mathrm{CD}^{+}{ }^{+} \mathrm{T}$ cells appear to be immunosuppressive [132], but in GCA, NKG2D has been reported to enhance the pathogenicity of Th1 and Th17 cells and stimulate the release of pro-inflammatory cytokines such as IFN $\gamma$ and Granulocyte-macrophage colony-stimulating factor (GMCSF), which are both important pathogenic players [129, 133, 134].

\section{Treg cell aging}

Treg cells are underestimated players in age-related diseases. The aging-induced decline of Treg numbers and function supports the general concept that the old immune system is pro-inflammatory. Failure of appropriately timed Treg-mediated immunosuppression has been considered relevant in the pathogenesis of GCA and TAK $[81,135]$. It is difficult to draw functional conclusions from phenotypic studies, both in the blood and in the lesion, and model systems are needed that permit genetic and/or pharmacologic manipulations of Treg to properly assess their role in disease. $\mathrm{CD} 8^{+}$Tregs normally suppress surrounding $\mathrm{CD} 4^{+} \mathrm{T}$ effector cells by secreting NADPH oxidase 2-(NOX2) containing microvesicles, which inhibit their target cells by interfering with signaling pathways via ROS. The release of NOX2 and the resulting suppressive capacity is sharply reduced in $\mathrm{CD} 8^{+}$ Tregs of older individuals and is even more pronounced in GCA patients $[65,66]$. The aberrant NOTCH signaling pathway is responsible for this dysfunctional $\mathrm{CD} 8^{+}$Treg activity. NOTCH4, one of 4 different NOTCH receptors, mediates intracellular vesicle trafficking by regulating the expression of its target genes RAB5A, RAB7A, and RAB11A [136]. The Rab (Ras related in the brain) proteins are involved in the formation and recycling process of microvesicles and are crucial for intra- and extracellular communication [137]. Jin et al. have demonstrated an upregulation of NOTCH4 and altered $\mathrm{RAB}$ gene transcription in $\mathrm{CD}^{+}$Treg cells from GCA patients. The expression of RAB5A and RAB7A was enhanced, whereas RAB11A was suppressed, resulting in a failure of surface translocation and release of NOX2-containing microvesicles [136]. Blocking NOTCH4 signaling was sufficient to restore the immunosuppressive function of Tregs in vivo and to suppress vessel wall inflammation [136].

Forkhead box protein P3 (FoxP3), a transcription factor, functions as a regulatory protein in the development, polarization, and function of Treg cells. When alternatively spliced, FoxP3 generates four distinct isoforms determining the activity level and phenotype of Treg cells [138]. In GCA patients with active disease, peripheral $\mathrm{CD} 4^{+}$Treg cells preferentially express FoxP $3 \Delta 2$ over the full-length isoform [139]. Tregs lacking exon 2 lose their suppressive function and even become pathogenic by producing IL-17 [140]. However, it is not known if this alteration has functional consequences in the disease process. Another mechanism that favors polarization toward Th17 cells over Treg cells is controlled by IL-6. IL-6, together with IL-21 and IL-23, blocks FoxP3 and stimulates ROR $\gamma \mathrm{t}$, a transcription factor responsible for Th17 polarization [141, 142]. IL-6, a marker cytokine of older individuals [143, 144], is elevated in both GCA and TAK and could modulate Treg functions [81, 145].

There is limited data investigating the role of Treg cells in TAK, and their role in the pathogenesis of TAK differs from GCA [145]. Kong et al. have reported a reduction in circulating Tregs compared with controls, whereas Matsumoto et al. could not confirm this finding [145, 146]. Gao et al. found a decrease of circulating Th2-like Tregs, a dysfunctional Treg cell subset, in TAK patients [147]. The authors propose that the reduction in circulating Th2-like Treg cells might reflect 
a drift from the blood into the vascular wall, where they fail to control other immune cells and release pro-inflammatory cytokines.

\section{Age-associated cytokine production}

An interesting and possibly age-related difference between GCA and TAK is effector cytokine production. In GCA, Th1 and Th17 are both encountered as effector cytokines in the inflamed vessel wall of GCA patients [148]. Lesional Th17 cells in GCA are responsive to corticosteroids, whereas Th1 cells persist despite prolonged treatment, suggesting that old IFN- $\gamma$-producing Th1 cells are resistant to immunosuppression. IFN- $\gamma$ secretion may be one manifestation of $\mathrm{T}$ cell senescence. In contrast, Th1 cells are susceptible to corticosteroids, and Th17 cells are steroid-resistant in TAK [148, 149]. This may reflect a loss of plasticity in committed effector $\mathrm{T}$ cells in GCA versus TAK, compatible with immune aging as a disease risk factor.

\section{Age-dependent epigenetic regulation}

An important aspect of the aging process is exposure to environmental stimuli which may leave long-lasting imprints in the immune system and in immuno-responsiveness. Epigenetic studies explore how environmental factors modify chromosomes without changing the underlying gene sequence, ultimately resulting in altered gene expression [150]. Epigenetic mechanisms regulate transcription factor accessibility to certain DNA regions and ultimately gene transcription. This is regulated by chemical modifications of DNA itself, such as methylation of cytosines, modification of histones, and by the interference of noncoding microRNA (miRNA) causing posttranscriptional gene silencing [151, 152]. Progressive age is associated with a variety of epigenetic changes, such as hyper- and hypomethylation of DNA, altered histone expression and modification, as well as dysregulation of miRNA expression [84, 153, 154]. DNA methylation is essential for the regulation of subset-specific $T$ cell gene expression and generally declines with age, causing overexpression of certain genes. However, some tissuespecific $\mathrm{CpG}$ have also been found to be hypermethylated with age [84]. Epigenomic studies of human $\mathrm{CD}^{+} \mathrm{T}$ cells have yielded evidence for progressively declining chromatin accessibility at gene promoters with age, resulting in a decrease in NRF1 binding [155]. Old naïve $\mathrm{CD} 8^{+} \mathrm{T}$ cells failed to transcribe respiratory chain genes, causing a collapse in mitochondrial function, specifically in oxidative phosphorylation [155].

A genome-wide methylation array of GCA versus nonGCA temporal arteries revealed hypomethylation of signature $\mathrm{T}$ cell $\mathrm{CpG}$ related to TCR/CD28 signaling, proinflammatory cytokine production (e.g., IFNG, IL6, IL21,
IL23R, IL17RA), and the calcineurin $(\mathrm{CaN}) /$ nuclear factor of activated T cells (NFAT) pathway [156, 157]. These findings are in line with the accumulation of highly activated $\mathrm{T}$ cells in the vasculitic lesions. Alteration of miRNA expression contributes to aging, including endothelial dysfunction, vascular inflammation, and compromised angiogenesis. A single miRNA can control the expression of multiple genes by inducing mRNA degradation or inhibiting the translation of certain mRNA strands [158]. miR-21, miR-146a, miR146b-5p, and miR-155 appear to be upregulated in actively inflamed GCA temporal artery biopsies compared to nonactive GCA and healthy arteries [159]. However, miRNA target protein expression was indistinguishable among the groups, and miRNA expression patterns in peripheral PBMCs were similar in all three populations. In essence, DNA methylation and miRNA expression appear to be altered with age and in GCA patients; however, the impact of these alterations on GCA pathogenesis remains to be clarified.

Most genetic risk variants found in GCA and TAK are clustered in noncoding DNA regions like enhancers, indicating that they may be disease-promoting by influencing the expression of regulatory risk genes [160]. Epigenetic changes affecting the interaction between the IL- 6 gene and the anti-inflammatory gene GPNMB may increase susceptibility for TAK. Specifically, the TAK-associated risk allele rs2069837 A/G in the enhancer region of the IL-6 gene mediates an increased inflammatory response in macrophages through chromatin looping and histone deacetylation that results in suppression of the anti-inflammatory gene GPNMB [145]. Another single nucleotide polymorphism (SNP) found in GCA and TAK that regulates epigenetic gene modification involves the KDM4C gene. KDM4C encodes a trimethylation-specific demethylase that regulates histone methylation and thereby chromatin compaction and transcription [161]. In addition to involvement in cell growth of different cancer cells and cytokine production, KDM4C regulates Jagged 1 expression in colonic carcinoma cells [162] and Jagged 1 is aberrantly expressed in GCA-affected tissues [114]. However, the impact of the KDM4C SNP and the functional consequences in GCA and TAK remain to be investigated.

\section{The microbiome as a risk factor for autoimmune vasculitis}

Major microbial exposure for humans is their gut microbiome, which may also be subject to age-induced changes. It is now estimated that the human body harbors as many bacterial cells as human cells, emphasizing the potential impact of host-microbial interactions in modulating immunocompetence and disease risk $[163,164]$. A variety of factors can shape the human microbiome, including the aging process. 


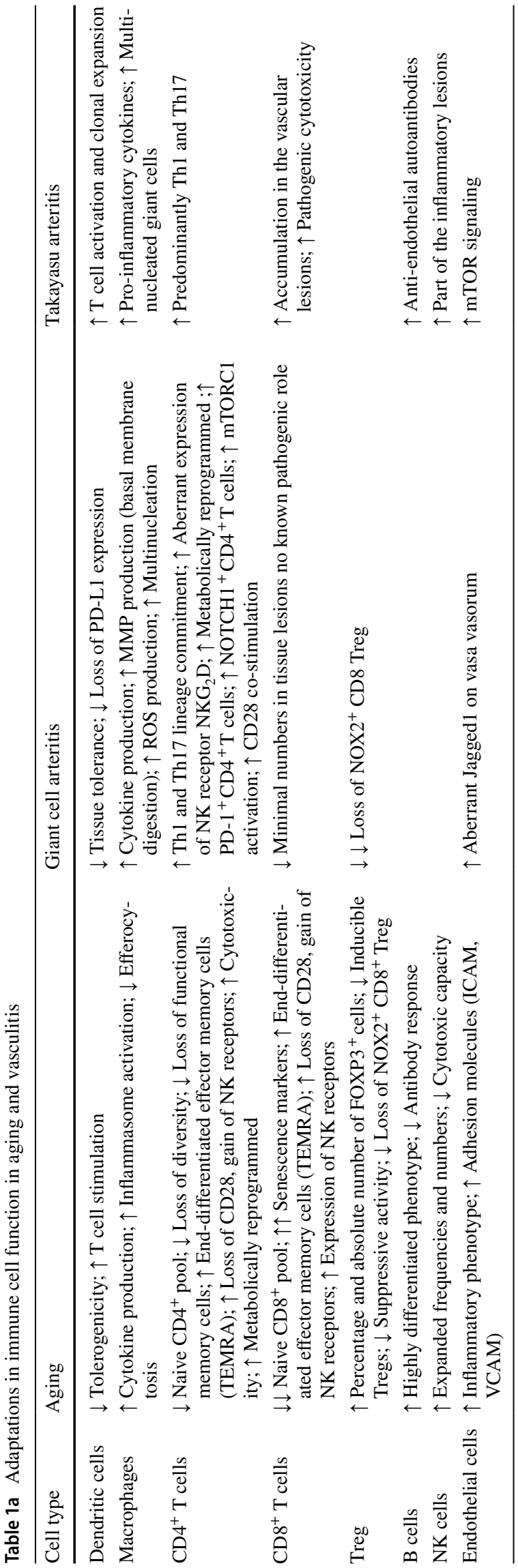

Conversely, the microbiome is crucially involved in organismal aging, and gut dysbiosis is recognized in many agerelated morbidities [165]. The transfer of the gut microbiome from old mice to young, germ-free mice causes inflammatory processes similar to "inflammaging" [166]. The intestinal microbiome has been implicated in the development of autoimmune diseases such as inflammatory bowel disease (IBD), lupus erythematosus, and multiple sclerosis [167]. Segmental filamentous bacteria (SFB) induce Th17 cells in mice and thereby promote inflammation, whereas Clostridia strains enhance polarization toward anti-inflammatory Treg cells $[168,169]$. Aging-induced gut dysbiosis could have a place in GCA, but experimental data supporting a mechanistic link are lacking [170-172].

Likewise, there are limited data about the role of the gut microbiome in TAK. The association of TAK and IBD is intriguing as gut dysbiosis is a key inducer of IBD [173, 174]. Besides changes in diversity and composition of the gut microbiome, alterations in metabolites produced by gut flora, such as short-chain fatty acids (SCFA), have relevance in IBD. Such metabolites essentially participate in various regulatory processes of the host, such as histone modulation, energy metabolism, and immune responses [173, 175]. One example is butyrate, which is decreased in IBD and can have immunomodulatory effects by altering the phenotype of macrophages and regulating Treg cell proliferation [176, 177]. These findings and the potential role in TAK warrant further investigation.

The interplay between the gut microbiome, epigenetics, and the immune system highlights the importance of environmental factors such as food, drugs, toxins, and physical activity as modulators of disease risk and disease course. Here, aging-imposed shifts could have a major impact on host-environment interactions, opening the door for lifestyle modifications as promising and cost-effective therapeutic tools $[178,179]$.

\section{Conclusions and future perspectives}

The primary risk factor for the two granulomatous vasculitides, GCA and TAK, is the age of the patient: the young being susceptible to TAK and the old being susceptible to GCA. The dichotomy of host age in the two diseases should shed light on possible etiologic agents, the composition and function of pathogenic cell populations, and the response patterns of the blood vessel. Aging is an inevitable part of life and is now recognized to cause profound restructuring of the immune system, manifesting with a high risk of older adults to suffer from infections, cancers, neurodegeneration, and cardiovascular disease. The older immune system typically combines immunodeficiency with heightened 


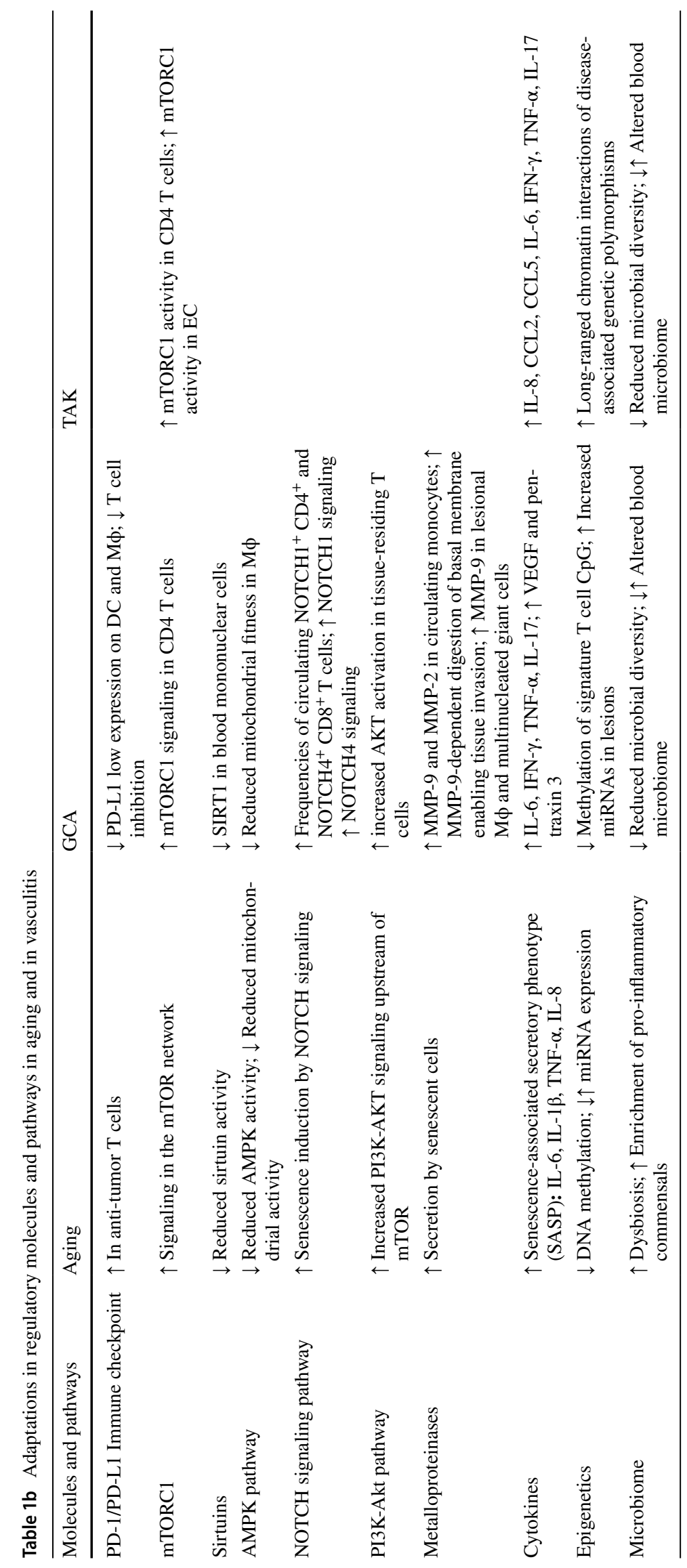


inflammatory activity, often referred to as "inflammaging" (Fig. 1). Therefore, discussions about the abnormal immunity in GCA need to be placed into the context of immune aging.

The older immune system exemplifies all hallmarks of aging: genomic instability, telomere shortening, altered epigenetic landscape, failing proteostasis, declining mitochondrial fitness, cellular senescence, deficient nutrient sensing, exhaustion of stem cell populations, and accumulation of stem cell mutations. Alignment of these hallmarks of aging with pathogenic events in GCA points toward the age-related failure of $\mathrm{CD} 8^{+} \mathrm{T}$ cells as a disease-relevant mechanism. $\mathrm{CD} 8^{+} \mathrm{T}$ cells, equipped with cytotoxic function, are present in the vasculitic lesions of TAK patients (Fig. 4), but rare in the vasculitic lesions of GCA (Fig. 5). $\mathrm{CD} 8^{+}$Treg cells are deficient in GCA patients, where their failure may facilitate the unopposed activity of $\mathrm{CD} 4^{+}$effector $\mathrm{T}$ cells. Aberrant mTORC1 activation in GCA CD4 $4^{+} \mathrm{T}$ cells mirrors the loss-of-control in the mTOR signaling network of old T cells (Fig. 6). Finally, metabolic signals controlling the PD-1/PD-L1 immune checkpoint, known to lose its tissueprotective function in GCA, may partially weaken due to age-imposed breakdown of intercellular communication.

Emerging data emphasize the impact of the aging process on epigenetic landscapes in immune cells. Increased understanding of how the bioenergetics within and around cells influence cellular function through the generation of ATP and "signaling" metabolites will be informative about cell fate decisions and microenvironmental cues guiding inflammatory processes. Insights from studies of the host microbiome in cancer, cardiovascular disease, and in other autoimmune diseases may provide useful insights into how and why patients form granulomatous infiltrates in arterial walls. Ultimately, the perspective of the patient's age will not only be important in understanding pathogenesis, but equally impactful in therapeutic management. TAK requires treatment for a lifetime; GCA occurs in individuals with a remaining life expectancy of 1-1.5 decades. Immunosuppressive interventions should be adapted to the youthful immune system of the TAK patients and the compromised immune system of the GCA patient Tables 1 and 2.

Acknowledgements Due to the size of the research field, not all relevant literature examining the immune aging process could be cited. The authors would like to acknowledge the patients who donated tissues for research studies.

Funding This work was supported by the National Institutes of Health (R01 AR042527, R01 HL117913, R01 AI108906, R01 HL142068, and P01 HL129941) to CMW and R01 AI108891, R01 AG045779, U19 AI057266, R01 AI129191 to JJG. ADG received fellowship support through the SGR research price 2019 sponsored by AbbVie Switzerland.

\section{Declarations}

Competing interests The authors declare no competing interests.

Open Access This article is licensed under a Creative Commons Attribution 4.0 International License, which permits use, sharing, adaptation, distribution and reproduction in any medium or format, as long as you give appropriate credit to the original author(s) and the source, provide a link to the Creative Commons licence, and indicate if changes were made. The images or other third party material in this article are included in the article's Creative Commons licence, unless indicated otherwise in a credit line to the material. If material is not included in the article's Creative Commons licence and your intended use is not permitted by statutory regulation or exceeds the permitted use, you will need to obtain permission directly from the copyright holder. To view a copy of this licence, visit http://creativecommons.org/licenses/by/4.0/.

\section{References}

1. Richards BL, March L, Gabriel SE (2010) Epidemiology of large-vessel vasculidities. Best Pract Res Clin Rheumatol 24(6):871-883

2. Trachtenberg BH, Hare JM (2017) Inflammatory cardiomyopathic syndromes. Circ Res 121(7):803-818

3. Ridker PM, Everett BM, Thuren T, MacFadyen JG, Chang WH, Ballantyne C et al (2017) Antiinflammatory therapy with canakinumab for atherosclerotic disease. N Engl J Med 377(12):1119-1131

4. Nidorf SM, Fiolet ATL, Mosterd A, Eikelboom JW, Schut A, Opstal TSJ et al (2020) Colchicine in patients with chronic coronary disease. N Engl J Med 383(19):1838-1847

5. Jaiswal S, Natarajan P, Silver AJ, Gibson CJ, Bick AG, Shvartz E et al (2017) Clonal hematopoiesis and risk of atherosclerotic cardiovascular disease. N Engl J Med 377(2):111-121

6. Bick AG, Pirruccello JP, Griffin GK, Gupta N, Gabriel S, Saleheen D et al (2020) Genetic interleukin 6 signaling deficiency attenuates cardiovascular risk in clonal hematopoiesis. Circulation 141(2):124-131

7. Nachun D, Lu AT, Bick AG, Natarajan P, Weinstock J, Szeto $\mathrm{MD}$, et al 2021 Clonal hematopoiesis associated with epigenetic aging and clinical outcomes. Aging Cell. 206 e13366.

8. Hunder GG, Bloch DA, Michel BA, Stevens MB, Arend WP, Calabrese LH et al (1990) The American College of Rheumatology 1990 criteria for the classification of giant cell arteritis. Arthritis Rheum 33(8):1122-1128

9. Arend WP, Michel BA, Bloch DA, Hunder GG, Calabrese LH, Edworthy SM et al (1990) The American College of Rheumatology 1990 criteria for the classification of Takayasu arteritis. Arthritis Rheum 33(8):1129-1134

10. Kennedy BK, Berger SL, Brunet A, Campisi J, Cuervo AM, Epel ES et al (2014) Geroscience: linking aging to chronic disease. Cell 159(4):709-713

11. Mallapaty S (2020) The coronavirus is most deadly if you are older and male - new data reveal the risks. Nature 585(7823): 16-17

12. "Life expectancy and healthy life expectancy, data by country". World Health Organization. 2020. [Available from: https://apps. who.int/gho/data/node.main.688.

13. López-Otín C, Blasco MA, Partridge L, Serrano M, Kroemer G (2013) The hallmarks of aging. Cell 153(6):1194-1217

14. Salvioli S, Monti D, Lanzarini C, Conte M, Pirazzini C, Bacalini MG et al (2013) Immune system, cell senescence, aging 
and longevity - inflamm-aging reappraised. Curr Pharm Des 19(9):1675-1679

15. Franceschi C, Bonafè M, Valensin S, Olivieri F, De Luca M, Ottaviani E, et al 2000 Inflamm-aging. An evolutionary perspective on immunosenescence. Ann N Y Acad Sci. 90824454.

16. Gustafson CE, Kim C, Weyand CM, Goronzy JJ (2020) Influence of immune aging on vaccine responses. J Allergy Clin Immunol 145(5):1309-1321

17. Fernandes M, Wan C, Tacutu R, Barardo D, Rajput A, Wang J et al (2016) Systematic analysis of the gerontome reveals links between aging and age-related diseases. Hum Mol Genet 25(21):4804-4818

18. Goronzy JJ, Weyand CM (2013) Understanding immunosenescence to improve responses to vaccines. Nat Immunol 14(5):428-436

19. Weyand CM, Goronzy JJ 2016 Aging of the immune system. Mechanisms and Therapeutic Targets. Ann Am Thorac Soc. 13 Suppl 5:S422-S8.

20. Zhang H, Weyand CM, Goronzy JJ 2021 Hallmarks of the aging T-cell system. FEBS J.

21. Watanabe R, Berry GJ, Liang DH, Goronzy JJ, Weyand CM (2020) Pathogenesis of giant cell arteritis and Takayasu arteritis - similarities and differences. Curr Rheumatol Rep 22(10):68

22. Aiello A, Farzaneh F, Candore G, Caruso C, Davinelli S, Gambino CM et al (2019) Immunosenescence and its hallmarks: how to oppose aging strategically? A review of potential options for therapeutic intervention. Front Immunol 10:2247

23. De Maeyer RPH, Chambers ES (2021) The impact of ageing on monocytes and macrophages. Immunol Lett 230:1-10

24. Panda A, Qian F, Mohanty S, van Duin D, Newman FK, Zhang L et al (2010) Age-associated decrease in TLR function in primary human dendritic cells predicts influenza vaccine response. J Immunol 184(5):2518-2527

25. Agrawal A, Sridharan A, Prakash S, Agrawal H (2012) Dendritic cells and aging: consequences for autoimmunity. Expert Rev Clin Immunol 8(1):73-80

26. Calcinotto A, Kohli J, Zagato E, Pellegrini L, Demaria M, Alimonti A (2019) Cellular senescence: aging, cancer, and injury. Physiol Rev 99(2):1047-1078

27. Rhinn M, Ritschka B, Keyes WM 2019 Cellular senescence in development, regeneration and disease. Development. 14620

28. Salama R, Sadaie M, Hoare M, Narita M (2014) Cellular senescence and its effector programs. Genes Dev 28(2):99-114

29. Faget DV, Ren Q, Stewart SA (2019) Unmasking senescence: context-dependent effects of SASP in cancer. Nat Rev Cancer 19(8):439-453

30. Chamoto K, Al-Habsi M, Honjo T (2017) Role of PD-1 in Immunity and Diseases. Curr Top Microbiol Immunol 410:75-97

31. Wang D, Du J, Song Y, Wang B, Song R, Hao Y et al (2020) CD70 contributes to age-associated $\mathrm{T}$ cell defects and overwhelming inflammatory responses. Aging (Albany NY) 12(12):12032-12050

32. Prattichizzo F, Bonafè M, Olivieri F, Franceschi C (2016) Senescence associated macrophages and "macroph-aging": are they pieces of the same puzzle? Aging (Albany NY) 8(12):3159-3160

33. Yoon P, Keylock KT, Hartman ME, Freund GG, Woods JA (2004) Macrophage hypo-responsiveness to interferon-gamma in aged mice is associated with impaired signaling through JakSTAT. Mech Ageing Dev 125(2):137-143

34. Mahbub S, Deburghgraeve CR, Kovacs EJ (2012) Advanced age impairs macrophage polarization. J Interferon Cytokine Res 32(1):18-26

35. Tasat DR, Mancuso R, O'Connor S, Molinari B (2003) Agedependent change in reactive oxygen species and nitric oxide generation by rat alveolar macrophages. Aging Cell 2(3):159-164
36. Feldman N, Rotter-Maskowitz A, Okun E (2015) DAMPs as mediators of sterile inflammation in aging-related pathologies. Ageing Res Rev 24(Pt A):29-39

37. Netea MG, Joosten LA, Latz E, Mills KH, Natoli G, Stunnenberg HG, et al 2016 Trained immunity: a program of innate immune memory in health and disease. Science. 3526284 aaf1098

38. Locati M, Curtale G, Mantovani A (2020) Diversity, mechanisms, and significance of macrophage plasticity. Annu Rev Pathol 15:123-147

39. van der Heijden CDCC, Noz MP, Joosten LAB, Netea MG, Riksen NP, Keating ST (2018) Epigenetics and trained immunity. Antioxid Redox Signal 29(11):1023-1040

40. Jan M, Ebert BL, Jaiswal S (2017) Clonal hematopoiesis. Semin Hematol 54(1):43-50

41. Libby P, Sidlow R, Lin AE, Gupta D, Jones LW, Moslehi J et al (2019) Clonal hematopoiesis: crossroads of aging, cardiovascular disease, and cancer: JACC review topic of the week. J Am Coll Cardiol 74(4):567-577

42. Beck DB, Ferrada MA, Sikora KA, Ombrello AK, Collins JC, Pei $\mathrm{W}$ et al (2020) Somatic mutations in UBA1 and severe adult-onset autoinflammatory disease. N Engl J Med 383(27):2628-2638

43. Lythe G, Callard RE, Hoare RL, Molina-París C (2016) How many TCR clonotypes does a body maintain? J Theor Biol 389:214-224

44. Qi Q, Liu Y, Cheng Y, Glanville J, Zhang D, Lee JY et al (2014) Diversity and clonal selection in the human T-cell repertoire. Proc Natl Acad Sci U S A 111(36):13139-13144

45. Goronzy JJ, Lee WW, Weyand CM (2007) Aging and T-cell diversity. Exp Gerontol 42(5):400-406

46. Wagner UG, Koetz K, Weyand CM, Goronzy JJ (1998) Perturbation of the $\mathrm{T}$ cell repertoire in rheumatoid arthritis. Proc Natl Acad Sci U S A 95(24):14447-14452

47. Murray JM, Kaufmann GR, Hodgkin PD, Lewin SR, Kelleher AD, Davenport MP et al (2003) Naive T cells are maintained by thymic output in early ages but by proliferation without phenotypic change after age twenty. Immunol Cell Biol 81(6):487-495

48. Germain RN (2012) Maintaining system homeostasis: the third law of Newtonian immunology. Nat Immunol 13(10):902-906

49. Fujii H, Shao L, Colmegna I, Goronzy JJ, Weyand CM (2009) Telomerase insufficiency in rheumatoid arthritis. Proc Natl Acad Sci U S A 106(11):4360-4365

50. den Braber I, Mugwagwa T, Vrisekoop N, Westera L, Mögling R, de Boer AB et al (2012) Maintenance of peripheral naive T cells is sustained by thymus output in mice but not humans. Immunity 36(2):288-297

51. Tanno H, Gould TM, McDaniel JR, Cao W, Tanno Y, Durrett RE et al (2020) Determinants governing T cell receptor $\alpha / \beta$-chain pairing in repertoire formation of identical twins. Proc Natl Acad Sci U S A 117(1):532-540

52. Semmes EC, Hurst JH, Walsh KM, Permar SR (2020) Cytomegalovirus as an immunomodulator across the lifespan. Curr Opin Virol 44:112-120

53. J Heath J, D Grant M 2020 The immune response against human cytomegalovirus links cellular to systemic senescence. Cells. 93

54. Weltevrede M, Eilers R, de Melker HE, van Baarle D (2016) Cytomegalovirus persistence and T-cell immunosenescence in people aged fifty and older: a systematic review. Exp Gerontol 77:87-95

55. Kim C, Jin J, Weyand CM, Goronzy JJ 2020 The transcription factor TCF1 in T cell differentiation and aging. Int J Mol Sci. 21 18

56. Klenerman P (2018) The (gradual) rise of memory inflation. Immunol Rev 283(1):99-112

57. Wherry EJ, Kurachi M (2015) Molecular and cellular insights into T cell exhaustion. Nat Rev Immunol 15(8):486-499 
58. Liuzzo G, Kopecky SL, Frye RL, O’Fallon WM, Maseri A, Goronzy JJ et al (1999) Perturbation of the T-cell repertoire in patients with unstable angina. Circulation 100(21):2135-2139

59. Liuzzo G, Goronzy JJ, Yang H, Kopecky SL, Holmes DR, Frye RL et al (2000) Monoclonal T-cell proliferation and plaque instability in acute coronary syndromes. Circulation 101(25):2883-2888

60. Liuzzo G, Vallejo AN, Kopecky SL, Frye RL, Holmes DR, Goronzy JJ et al (2001) Molecular fingerprint of interferon-gamma signaling in unstable angina. Circulation 103(11):1509-1514

61. Nakajima T, Goek O, Zhang X, Kopecky SL, Frye RL, Goronzy JJ et al (2003) De novo expression of killer immunoglobulinlike receptors and signaling proteins regulates the cytotoxic function of CD4 T cells in acute coronary syndromes. Circ Res 93(2):106-113

62. Jagger A, Shimojima Y, Goronzy JJ, Weyand CM (2014) Regulatory $\mathrm{T}$ cells and the immune aging process: a mini-review. Gerontology 60(2):130-137

63. Zhao L, Sun L, Wang H, Ma H, Liu G, Zhao Y (2007) Changes of CD4+CD25+Foxp3+ regulatory T cells in aged Balb/c mice. J Leukoc Biol 81(6):1386-1394

64. Suzuki M, Jagger AL, Konya C, Shimojima Y, Pryshchep S, Goronzy JJ et al (2012) CD8+CD45RA+CCR7+FOXP3+ $T$ cells with immunosuppressive properties: a novel subset of inducible human regulatory $\mathrm{T}$ cells. J Immunol 189(5):2118-2130

65. Wen Z, Shimojima Y, Shirai T, Li Y, Ju J, Yang Z et al (2016) NADPH oxidase deficiency underlies dysfunction of aged CD8+ Tregs. J Clin Invest 126(5):1953-1967

66. Hu B, Jadhav RR, Gustafson CE, Le Saux S, Ye Z, Li X, et al 2020 Distinct age-related epigenetic signatures in CD4 and CD8 T cells. Front Immunol. 11585168

67. van Gisbergen KPJM, Zens KD, Münz C (2021) T-cell memory in tissues. Eur J Immunol 51(6):1310-1324

68. Ryan GE, Harris JE, Richmond JM 2020 Resident memory T cells in autoimmune skin diseases. Front Immunol. 12652191

69. Watanabe C, Imaizumi T, Kawai H, Suda K, Honma Y, Ichihashi M, et al 2020 Aging of the vascular system and neural diseases. Front Aging Neurosci. 12557384

70. Wagner AD, Björnsson J, Bartley GB, Goronzy JJ, Weyand CM (1996) Interferon-gamma-producing $T$ cells in giant cell vasculitis represent a minority of tissue-infiltrating cells and are located distant from the site of pathology. Am J Pathol 148(6): 1925-1933

71. Seeland U, Nemcsik J, Lønnebakken MT, Kublickiene K, Schluchter H, Park C et al (2021) Sex and gender aspects in vascular ageing - focus on epidemiology, pathophysiology, and outcomes. Heart Lung Circ 30(11):1637-1646

72. Ribeiro-Silva JC, Nolasco P, Krieger JE, Miyakawa AA 2021 Dynamic crosstalk between vascular smooth muscle cells and the aged extracellular matrix. Int J Mol Sci. 2218

73. Buglak NE, Batrakova EV, Mota R, Bahnson ESM (2018) Insights on localized and systemic delivery of redox-based therapeutics. Oxid Med Cell Longev 2018:2468457

74. Ungvari Z, Tarantini S, Sorond F, Merkely B, Csiszar A (2020) Mechanisms of vascular aging, a geroscience perspective: JACC Focus Seminar. J Am Coll Cardiol 75(8):931-941

75. Fournet M, Bonté F, Desmoulière A (2018) Glycation damage: a possible hub for major pathophysiological disorders and aging. Aging Dis 9(5):880-900

76. Wang M, Spinetti G, Monticone RE, Zhang J, Wu J, Jiang L, et al 2011 A local proinflammatory signalling loop facilitates adverse age-associated arterial remodeling. PLoS One. 62 e16653.
77. Duca L, Blaise S, Romier B, Laffargue M, Gayral S, El Btaouri H et al (2016) Matrix ageing and vascular impacts: focus on elastin fragmentation. Cardiovasc Res 110(3):298-308

78. Machado-Oliveira G, Ramos C, Marques ARA, Vieira OV 2020 Cell senescence, multiple organelle dysfunction and atherosclerosis. Cells. 910

79. Sawabe M (2010) Vascular aging: from molecular mechanism to clinical significance. Geriatr Gerontol Int 10(Suppl 1):S213-S220

80. Weyand CM, Goronzy JJ (2013) Immune mechanisms in medium and large-vessel vasculitis. Nat Rev Rheumatol 9(12):731-740

81. Borchers AT, Gershwin ME (2012) Giant cell arteritis: a review of classification, pathophysiology, geoepidemiology and treatment. Autoimmun Rev 11(6-7):A544-A554

82. Kerr GS, Hallahan CW, Giordano J, Leavitt RY, Fauci AS, Rottem M et al (1994) Takayasu arteritis. Ann Intern Med 120(11):919-929

83. Goronzy JJ, Hu B, Kim C, Jadhav RR, Weyand CM (2018) Epigenetics of T cell aging. J Leukoc Biol 104(4):691-699

84. Weyand CM, Goronzy JJ (2021) The immunology of rheumatoid arthritis. Nat Immunol 22(1):10-18

85. Weyand CM, Schönberger J, Oppitz U, Hunder NN, Hicok KC, Goronzy JJ (1994) Distinct vascular lesions in giant cell arteritis share identical T cell clonotypes. J Exp Med 179(3):951-960

86. Shirai T, Hilhorst M, Harrison DG, Goronzy JJ, Weyand CM (2015) Macrophages in vascular inflammation - from atherosclerosis to vasculitis. Autoimmunity 48(3):139-151

87. Pryshchep O, Ma-Krupa W, Younge BR, Goronzy JJ, Weyand CM (2008) Vessel-specific toll-like receptor profiles in human medium and large arteries. Circulation 118(12):1276-1284

88. Krupa WM, Dewan M, Jeon MS, Kurtin PJ, Younge BR, Goronzy JJ et al (2002) Trapping of misdirected dendritic cells in the granulomatous lesions of giant cell arteritis. Am J Pathol 161(5):1815-1823

89. Zhang H, Watanabe R, Berry GJ, Nadler SG, Goronzy JJ, Weyand CM (2019) CD28 signaling controls metabolic fitness of pathogenic $\mathrm{T}$ cells in medium and large vessel vasculitis. J Am Coll Cardiol 73(14):1811-1823

90. Zhang H, Watanabe R, Berry GJ, Vaglio A, Liao YJ, Warrington $\mathrm{KJ}$ et al (2017) Immunoinhibitory checkpoint deficiency in medium and large vessel vasculitis. Proc Natl Acad Sci U S A 114(6):E970-E979

91. Alsaab HO, Sau S, Alzhrani R, Tatiparti K, Bhise K, Kashaw SK et al (2017) PD-1 and PD-L1 checkpoint signaling inhibition for cancer immunotherapy: mechanism, combinations, and clinical outcome. Front Pharmacol 8:561

92. Goldstein BL, Gedmintas L, Todd DJ (2014) Drug-associated polymyalgia rheumatica/giant cell arteritis occurring in two patients after treatment with ipilimumab, an antagonist of ctla4. Arthritis Rheumatol 66(3):768-769

93. Brahmer JR, Tykodi SS, Chow LQ, Hwu WJ, Topalian SL, Hwu $P$ et al (2012) Safety and activity of anti-PD-L1 antibody in patients with advanced cancer. N Engl J Med 366(26):2455-2465

94. Gibon E, Loi F, Córdova LA, Pajarinen J, Lin T, Lu L et al (2016) Aging affects bone marrow macrophage polarization: relevance to bone healing. Regen Eng Trans1 Med 2(2):98-104

95. Skuratovskaia D, Vulf M, Khaziakhmatova O, Malashchenko V, Komar A, Shunkin E, et al 2020 Tissue-specific role of macrophages in noninfectious inflammatory disorders. Biomedicines. 810

96. Watanabe R, Maeda T, Zhang H, Berry GJ, Zeisbrich M, Brockett $\mathrm{R}$ et al (2018) MMP (matrix metalloprotease)-9-producing monocytes enable $\mathrm{T}$ cells to invade the vessel wall and cause vasculitis. Circ Res 123(6):700-715 
97. Watanabe R, Hilhorst M, Zhang H, Zeisbrich M, Berry GJ, Wallis BB, et al 2018 Glucose metabolism controls disease-specific signatures of macrophage effector functions. JCI Insight. 320

98. Wu G, Mahajan N, Dhawan V 2014 Acknowledged signatures of matrix metalloproteinases in Takayasu's arteritis. Biomed Res Int. 2014827105

99. Wang M, Takagi G, Asai K, Resuello RG, Natividad FF, Vatner DE et al (2003) Aging increases aortic MMP-2 activity and angiotensin II in nonhuman primates. Hypertension 41(6):1308-1316

100. Wang M, Monticone RE, McGraw KR (2020) Proinflammation, profibrosis, and arterial aging. Aging Med (Milton) 3(3):159-168

101. Shirai T, Nazarewicz RR, Wallis BB, Yanes RE, Watanabe R, Hilhorst $\mathrm{M}$ et al (2016) The glycolytic enzyme PKM2 bridges metabolic and inflammatory dysfunction in coronary artery disease. J Exp Med 213(3):337-354

102. Rittner HL, Kaiser M, Brack A, Szweda LI, Goronzy JJ, Weyand CM (1999) Tissue-destructive macrophages in giant cell arteritis. Circ Res 84(9):1050-1058

103. Sun N, Youle RJ, Finkel T (2016) The mitochondrial basis of aging. Mol Cell 61(5):654-666

104. Saxton RA, Sabatini DM (2017) mTOR signaling in growth, metabolism, and disease. Cell 169(2):361-371

105. Weichhart T (2018) mTOR as regulator of lifespan, aging, and cellular senescence: a mini-review. Gerontology 64(2):127-134

106. Perera RM, Zoncu R (2016) The lysosome as a regulatory hub. Annu Rev Cell Dev Biol 32:223-253

107. Saftig P, Haas A (2016) Turn up the lysosome. Nat Cell Biol 18(10):1025-1027

108. Arriola Apelo SI, Lamming DW (2016) Rapamycin: an inhibitor of aging emerges from the soil of easter island. J Gerontol A Biol Sci Med Sci 71(7):841-849

109. Maciejewski-Duval A, Comarmond C, Leroyer A, Zaidan M, Le Joncour A, Desbois AC et al (2018) mTOR pathway activation in large vessel vasculitis. J Autoimmun 94:99-109

110. Sadria M, Layton AT (2021) Interactions among mTORC, AMPK and SIRT: a computational model for cell energy balance and metabolism. Cell Commun Signal 19(1):57

111. Ianni A, Kumari P, Tarighi S, Argento FR, Fini E, Emmi G, et al 2021 An insight into giant cell arteritis pathogenesis: evidence for oxidative stress and SIRT1 downregulation. Antioxidants (Basel). 106

112. Watanabe R, Berry GJ, Liang DH, Goronzy JJ, Weyand CM 2020 Cellular signaling pathways in medium and large vessel vasculitis. Front Immunol. 11587089

113. Wen Z, Shen Y, Berry G, Shahram F, Li Y, Watanabe R, et al 2017 The microvascular niche instructs $\mathrm{T}$ cells in large vessel vasculitis via the VEGF-Jagged1-NOTCH pathway. Sci Transl Med. 9399

114. Radtke F, Wilson A, Mancini SJ, MacDonald HR (2004) NOTCH regulation of lymphocyte development and function. Nat Immunol 5(3):247-253

115. Balistreri CR, Madonna R, Melino G, Caruso C (2016) The emerging role of NOTCH pathway in ageing: focus on the related mechanisms in age-related diseases. Ageing Res Rev 29:50-65

116. Hans CP, Koenig SN, Huang N, Cheng J, Beceiro S, Guggilam A et al (2012) Inhibition of NOTCH1 signaling reduces abdominal aortic aneurysm in mice by attenuating macrophage-mediated inflammation. Arterioscler Thromb Vasc Biol 32(12):3012-3023

117. Cheng J, Koenig SN, Kuivaniemi HS, Garg V, Hans CP 2014 Pharmacological inhibitor of NOTCH signaling stabilizes the progression of small abdominal aortic aneurysm in a mouse model. J Am Heart Assoc. 36 e001064

118. Piggott K, Deng J, Warrington K, Younge B, Kubo JT, Desai $M$ et al (2011) Blocking the NOTCH pathway inhibits vascular inflammation in large-vessel vasculitis. Circulation 123(3):309-318
119. Hadjadj J, Canaud G, Mirault T, Samson M, Bruneval P, Régent A et al (2018) mTOR pathway is activated in endothelial cells from patients with Takayasu arteritis and is modulated by serum immunoglobulin G. Rheumatology (Oxford) 57(6):1011-1020

120. Mutoh T, Shirai T, Ishii T, Shirota Y, Fujishima F, Takahashi F et al (2020) Identification of two major autoantigens negatively regulating endothelial activation in Takayasu arteritis. Nat Commun 11(1): 1253

121. Heras-Sandoval D, Pérez-Rojas JM, Hernández-Damián J, Pedraza-Chaverri J (2014) The role of PI3K/AKT/mTOR pathway in the modulation of autophagy and the clearance of protein aggregates in neurodegeneration. Cell Signal 26(12):2694-2701

122. Seko Y, Minota S, Kawasaki A, Shinkai Y, Maeda K, Yagita H et al (1994) Perforin-secreting killer cell infiltration and expression of a $65-\mathrm{kD}$ heat-shock protein in aortic tissue of patients with Takayasu's arteritis. J Clin Invest 93(2):750-758

123. Kurata A, Saito A, Hashimoto H, Fujita K, Ohno SI, Kamma $\mathrm{H}$ et al (2019) Difference in immunohistochemical characteristics between Takayasu arteritis and giant cell arteritis: it may be better to distinguish them in the same age. Mod Rheumatol 29(6):992-1001

124. Czesnikiewicz-Guzik M, Lee WW, Cui D, Hiruma Y, Lamar DL, Yang ZZ et al (2008) T cell subset-specific susceptibility to aging. Clin Immunol 127(1):107-118

125. Goronzy JJ, Weyand CM (2017) Successful and maladaptive T cell aging. Immunity 46(3):364-378

126. Schmidt D, Goronzy JJ, Weyand CM (1996) CD4+ CD7CD28- $\mathrm{T}$ cells are expanded in rheumatoid arthritis and are characterized by autoreactivity. J Clin Invest 97(9):2027-2037

127. Nakajima T, Schulte S, Warrington KJ, Kopecky SL, Frye RL, Goronzy JJ et al (2002) T-cell-mediated lysis of endothelial cells in acute coronary syndromes. Circulation 105(5):570-575

128. Zhang Y, Wallace DL, de Lara CM, Ghattas H, Asquith B, Worth A et al (2007) In vivo kinetics of human natural killer cells: the effects of ageing and acute and chronic viral infection. Immunology 121(2):258-265

129. Dejaco C, Duftner C, Al-Massad J, Wagner AD, Park JK, Fessler J et al (2013) NKG2D stimulated T-cell autoreactivity in giant cell arteritis and polymyalgia rheumatica. Ann Rheum Dis 72(11):1852-1859

130. Groh V, Bruhl A, El-Gabalawy H, Nelson JL, Spies T (2003) Stimulation of $\mathrm{T}$ cell autoreactivity by anomalous expression of NKG2D and its MIC ligands in rheumatoid arthritis. Proc Natl Acad Sci U S A 100(16):9452-9457

131. de Menthon M, Lambert M, Guiard E, Tognarelli S, Bienvenu B, Karras A et al (2011) Excessive interleukin-15 transpresentation endows NKG2D+CD4+ T cells with innate-like capacity to lyse vascular endothelium in granulomatosis with polyangiitis (Wegener's). Arthritis Rheum 63(7):2116-2126

132. Dai Z, Turtle CJ, Booth GC, Riddell SR, Gooley TA, Stevens AM et al (2009) Normally occurring NKG2D+CD4+ T cells are immunosuppressive and inversely correlated with disease activity in juvenile-onset lupus. J Exp Med 206(4):793-805

133. Babic M, Dimitropoulos C, Hammer Q, Stehle C, Heinrich F, Sarsenbayeva A, et al 2020 NK cell receptor NKG2D enforces proinflammatory features and pathogenicity of Th1 and Th17 cells. J Exp Med. 2178

134. Jiemy WF, van Sleen Y, van der Geest KS, Ten Berge HA, Abdulahad WH, Sandovici M, et al 2020 Distinct macrophage phenotypes skewed by local granulocyte macrophage colonystimulating factor (GM-CSF) and macrophage colony-stimulating factor (M-CSF) are associated with tissue destruction and intimal hyperplasia in giant cell arteritis. Clin Transl Immunology. 99 e1164. 
135. Akiyama M, Ohtsuki S, Berry GJ, Liang DH, Goronzy JJ, Weyand CM 2020 Innate and adaptive immunity in giant cell arteritis. Front Immunol. 11621098

136. Jin K, Wen Z, Wu B, Zhang H, Qiu J, Wang Y, et al 2021 NOTCH-induced rerouting of endosomal trafficking disables regulatory T cells in vasculitis. J Clin Invest. 1311

137. Prashar A, Schnettger L, Bernard EM, Gutierrez MG (2017) Rab GTPases in immunity and inflammation. Front Cell Infect Microbiol 7:435

138. Kaur G, Goodall JC, Jarvis LB, Hill Gaston JS (2010) Characterisation of Foxp3 splice variants in human CD4+ and CD8+ $\mathrm{T}$ cells - identification of Foxp $3 \Delta 7$ in human regulatory $\mathrm{T}$ cells. Mol Immunol 48(1-3):321-332

139. Miyabe C, Miyabe Y, Strle K, Kim ND, Stone JH, Luster AD et al (2017) An expanded population of pathogenic regulatory $\mathrm{T}$ cells in giant cell arteritis is abrogated by IL-6 blockade therapy. Ann Rheum Dis 76(5):898-905

140. Joly AL, Liu S, Dahlberg CI, Mailer RK, Westerberg LS, Andersson J (2015) Foxp3 lacking exons 2 and 7 is unable to confer suppressive ability to regulatory $\mathrm{T}$ cells in vivo. $\mathrm{J}$ Autoimmun 63:23-30

141. Barbi J, Pardoll D, Pan F (2013) Metabolic control of the Treg/ Th17 axis. Immunol Rev 252(1):52-77

142. Kimura A, Kishimoto T (2010) IL-6: regulator of Treg/Th17 balance. Eur J Immunol 40(7):1830-1835

143. Lee JK, Bettencourt R, Brenner D, Le TA, Barrett-Connor E, Loomba R 2012 Association between serum interleukin-6 concentrations and mortality in older adults: the Rancho Bernardo study. PLoS One. 74 e34218.

144. Zhu S, Patel KV, Bandinelli S, Ferrucci L, Guralnik JM (2009) Predictors of interleukin-6 elevation in older adults. J Am Geriatr Soc 57(9):1672-1677

145. Kong X, Sun Y, Ma L, Chen H, Wei L, Wu W et al (2016) The critical role of IL-6 in the pathogenesis of Takayasu arteritis. Clin Exp Rheumatol 34(3 Suppl 97):S21-S27

146. Matsumoto K, Suzuki K, Yoshimoto K, Seki N, Tsujimoto H, Chiba K et al (2019) Significant association between clinical characteristics and changes in peripheral immuno-phenotype in large vessel vasculitis. Arthritis Res Ther 21(1):304

147. Gao N, Cui W, Zhao LM, Li TT, Zhang JH, Pan LL 2020 Contribution of Th2-like Treg cells to the pathogenesis of Takayasu's arteritis. Clin Exp Rheumatol. 38 Suppl 12424854.

148. Deng J, Younge BR, Olshen RA, Goronzy JJ, Weyand CM (2010) Th17 and Th1 T-cell responses in giant cell arteritis. Circulation 121(7):906-915

149. Saadoun D, Garrido M, Comarmond C, Desbois AC, Domont F, Savey L et al (2015) Th1 and Th17 cytokines drive inflammation in Takayasu arteritis. Arthritis Rheumatol 67(5):1353-1360

150. Berger SL, Kouzarides T, Shiekhattar R, Shilatifard A (2009) An operational definition of epigenetics. Genes Dev 23(7):781-783

151. Sen P, Shah PP, Nativio R, Berger SL (2016) Epigenetic mechanisms of longevity and aging. Cell 166(4):822-839

152. Yao Q, Chen Y, Zhou X (2019) The roles of microRNAs in epigenetic regulation. Curr Opin Chem Biol 51:11-17

153. Li Y, Liu Y, Strickland FM, Richardson B (2010) Age-dependent decreases in DNA methyltransferase levels and low transmethylation micronutrient levels synergize to promote overexpression of genes implicated in autoimmunity and acute coronary syndromes. Exp Gerontol 45(4):312-322

154. Dozmorov MG, Coit P, Maksimowicz-McKinnon K, Sawalha AH (2017) Age-associated DNA methylation changes in naive CD4. Epigenomics 9(4):429-445

155. Moskowitz DM, Zhang DW, Hu B, Le Saux S, Yanes RE, Ye Z, et al 2017 Epigenomics of human CD8 T cell differentiation and aging. Sci Immunol. 28
156. Coit P, De Lott LB, Nan B, Elner VM, Sawalha AH (2016) DNA methylation analysis of the temporal artery microenvironment in giant cell arteritis. Ann Rheum Dis 75(6):1196-1202

157. Renauer P, Coit P, Sawalha AH (2016) Epigenetics and vasculitis: a comprehensive review. Clin Rev Allergy Immunol 50(3):357-366

158. Kiss T, Giles CB, Tarantini S, Yabluchanskiy A, Balasubramanian P, Gautam T et al (2019) Nicotinamide mononucleotide (NMN) supplementation promotes anti-aging miRNA expression profile in the aorta of aged mice, predicting epigenetic rejuvenation and anti-atherogenic effects. Geroscience 41(4):419-439

159. Croci S, Zerbini A, Boiardi L, Muratore F, Bisagni A, Nicoli D et al (2016) MicroRNA markers of inflammation and remodelling in temporal arteries from patients with giant cell arteritis. Ann Rheum Dis 75(8):1527-1533

160. Sawalha AH, Dozmorov MG (2016) Epigenomic functional characterization of genetic susceptibility variants in systemic vasculitis. J Autoimmun 67:76-81

161. Ortiz-Fernández L, Carmona FD, López-Mejías R, GonzálezEscribano MF, Lyons PA, Morgan AW et al (2018) Cross-phenotype analysis of immunochip data identifies. Ann Rheum Dis 77(4):589-595

162. Yamamoto S, Tateishi K, Kudo Y, Yamamoto K, Isagawa T, Nagae G et al (2013) Histone demethylase KDM4C regulates sphere formation by mediating the cross talk between Wnt and NOTCH pathways in colonic cancer cells. Carcinogenesis 34(10):2380-2388

163. Sender R, Fuchs S, Milo R (2016) Are we really vastly outnumbered? Revisiting the ratio of bacterial to host cells in humans. Cell 164(3):337-340

164. Team NHMPA 2019 A review of 10 years of human microbiome research activities at the US National Institutes of Health, Fiscal Years 2007-2016. Microbiome. 7131.

165. Kim S, Jazwinski SM (2018) The gut microbiota and healthy aging: a mini-review. Gerontology 64(6):513-520

166. Fransen F, van Beek AA, Borghuis T, Aidy SE, Hugenholtz F, van der Gaast-de JC et al (2017) Aged gut microbiota contributes to systemical inflammaging after transfer to germ-free mice. Front Immunol 8:1385

167. Clemente JC, Manasson J, Scher JU 2018 The role of the gut microbiome in systemic inflammatory disease. BMJ. $360 \mathrm{j} 5145$.

168. Wu HJ, Ivanov II, Darce J, Hattori K, Shima T, Umesaki Y et al (2010) Gut-residing segmented filamentous bacteria drive autoimmune arthritis via T helper 17 cells. Immunity 32(6):815-827

169. Atarashi K, Tanoue T, Oshima K, Suda W, Nagano Y, Nishikawa $\mathrm{H}$ et al (2013) Treg induction by a rationally selected mixture of Clostridia strains from the human microbiota. Nature 500(7461):232-236

170. Ostrowski RA, Metgud S, Tehrani R, Jay WM (2019) Varicella zoster virus in giant cell arteritis: a review of current medical literature. Neuroophthalmology 43(3):159-170

171. Hoffman GS, Getz TM, Padmanabhan R, Villa-Forte A, Clifford AH, Funchain P et al (2019) The microbiome of temporal arteries. Pathog Immun 4(1):21-38

172. Thapa Magar M, Kafle S, Poudel A, Patel P, Cancarevic I 2021 Takayasu's arteritis and its association with mycobacterium tuberculosis: a systematic review. Cureus. 138 e16927.

173. Franzosa EA, Sirota-Madi A, Avila-Pacheco J, Fornelos N, Haiser HJ, Reinker S et al (2019) Gut microbiome structure and metabolic activity in inflammatory bowel disease. Nat Microbiol 4(2):293-305

174. Bai Y, Ahmad U, Wang Y, Li JH, Choy JC, Kim RW et al (2008) Interferon-gamma induces X-linked inhibitor of apoptosis-associated factor-1 and Noxa expression and potentiates human vascular smooth muscle cell apoptosis by STAT3 activation. J Biol Chem 283(11):6832-6842 
175. Schönfeld P, Wojtczak L (2016) Short- and medium-chain fatty acids in energy metabolism: the cellular perspective. J Lipid Res 57(6):943-954

176. Fernando MR, Saxena A, Reyes JL, McKay DM (2016) Butyrate enhances antibacterial effects while suppressing other features of alternative activation in IL-4-induced macrophages. Am J Physiol Gastrointest Liver Physiol 310(10):G822-G831

177. Smith PM, Howitt MR, Panikov N, Michaud M, Gallini CA, Bohlooly-Y M et al (2013) The microbial metabolites, shortchain fatty acids, regulate colonic Treg cell homeostasis. Science 341(6145):569-573

178. Aleksandrova K, Romero-Mosquera B, Hernandez V 2017 Diet, Gut microbiome and epigenetics: emerging links with inflammatory bowel diseases and prospects for management and prevention. Nutrients. 99

179. Mailing LJ, Allen JM, Buford TW, Fields CJ, Woods JA (2019) Exercise and the gut microbiome: a review of the evidence, potential mechanisms, and implications for human health. Exerc Sport Sci Rev 47(2):75-85

Publisher's Note Springer Nature remains neutral with regard to jurisdictional claims in published maps and institutional affiliations. 